\title{
The Mammalian Glucose Transporters
}

\author{
SHERIN U. DEVASKAR AND MIKE M. MUECKLER \\ Division of Neonatology, Department of Pediatrics, St. Louis University School of Medicine, The Pediatric \\ Research Institute and Cardinal Glennon Children's Hospital, St. Louis, Missouri 63104 /S.U.D.I and \\ Department of Cell Biology and Physiology, Washington University School of Medicine, \\ St. Louis, Missouri 63110 [M.M.M.]
}

Glucose is a key metabolic substrate for mammalian cells. Blood glucose is a precursor for the biosynthesis of glycogen and fat as well as various sugar-containing macromolecules, such as glycoproteins, glycolipids, and nucleic acids. Some tissues (e.g. brain) require glucose as an energy source, and other tissues (e.g. muscle) will preferentially catabolize glucose for ATP production when it is plentiful. The first step in the metabolism of blood glucose is transport across the plasma membrane. This step is carried out by a family of membrane carrier proteins called glucose transporters $(1,2)$. Surprisingly, a different family of proteins is responsible for the transfer of glucose across the apical membranes of polarized intestinal and renal epithelial cells. These sodium-glucose cotransporters are secondary active transport systems that appear to be evolutionarily unrelated to the facilitative glucose transporters.

One or more glucose transporters are present in nearly all mammalian cells because of the central role played by glucose in cellular metabolism. In most cell types, glucose transporters are only involved in the net uptake of blood glucose for cellular metabolism. However, in some tissues glucose transporters may participate in the net efflux of glucose from the cell into the blood. For example, this process occurs during the absorption or reabsorption of glucose across the intestinal or renal epithelia, where facilitative glucose transporters are present in the basolateral membrane and allow the passive flux of sugar down its concentration gradient into the blood. Additionally, transporters are involved in the net efflux of cellular glucose from cells of the liver or kidney during fasting.

Glucose transporters are thus involved in both increasing and decreasing blood glucose levels and are, therefore, perfectly positioned to participate in the regulation of glucose homeostasis. This review will focus on recent advances concerning the regulation of glucose transporters in several key mammalian tissues. First, we briefly describe some physical properties of the glucose transporter subtypes.

\section{GLUCOSE TRANSPORTER FAMILIES}

Sodium-glucose cotransporters. Sodium-glucose cotransporters have been described in rabbit and human small intestine (3-6) and rabbit kidney $(7,8)$. They are expressed by specialized epithelial cells, i.e. the mature enterocytes lining the intestinal microvillus tip (3), and the brush border of the proximal tubule of the kidney (9-11). This cotransporter actively pumps glucose from the intestinal or tubular lumen against its concentration

Received March 14, 1991; accepted August 21, 1991

Correspondence and reprint requests: Dr. Sherin U. Devaskar, 1465 South Grand Blvd., St. Louis, MO 63104.

S.U.D. is supported by research grants from NIH (HD-25024), American Diabetes Association, and Fleur-de-Lis, St. Louis, MO. M.M.M. is supported by research grants from NIH (DK 38495 and 43695), Juvenile Diabetes Foundation, and American Heart Association and is a recipient of a career development award from the Juvenile Diabetes Foundation. gradient by coupling the transport of glucose and sodium, the latter being transported down its concentration gradient. The sodium gradient is maintained by the active transport of sodium across the basolateral surface of the brush border cells by the membrane-bound $\mathrm{Na}+/ \mathrm{K}+/$ ATPase.

The sodium-glucose cotransporter consists of 662-664 amino acids and is predicted to traverse the cell membrane 11 times, with the $\mathrm{NH}_{2}$ and $\mathrm{COOH}$ termini located on the extracellular and cytoplasmic sides of the cell membrane, respectively (4). The protein is glycosylated at an asparagine residue in the small exofacial loop connecting transmembrane segments M5 and M6. The gene encoding the human intestinal sodium-glucose cotransporter, SGLT1, has been localized to the q11.2 $\rightarrow$ qter region of chromosome 22 (12).

Facilitative glucose transporters. The second major type of glucose transporter is expressed in nearly all mammalian cells $(13,14)$. These proteins transport glucose in an energy-independent process down a concentration gradient by stereospecific, saturable, facilitative diffusion. This class of transporters includes five isoforms that are encoded by different genes and exhibit distinct tissue distributions (Table 1), presumably reflecting the unique glucose requirements of various tissues $(13,14)$.

The facilitative glucose transporters vary in size from 492 to 524 amino acids. They exhibit $39-64 \%$ sequence identity and $50-76 \%$ sequence similarity in pair-wise comparisons (15-26). These transporters are predicted to traverse the cell membrane 12 times, with the $\mathrm{NH}_{2}$ and $\mathrm{COOH}$ termini, which vary in sequence and length between the different isoforms, located on the cytoplasmic side of the cell membrane. An exofacial loop between transmembrane segments $\mathrm{M} 1$ and $\mathrm{M} 2$ carries the site for asparagine-linked glycosylation. A large intracellular hydrophilic segment exists between M6 and M7 (Fig. 1) (15). Comparisons between the different isoforms have revealed that the sequences of the transmembrane segments and the short cytoplasmic loops connecting these transmembrane regions are highly conserved. Thus, it is thought that these regions subserve a common function, such as the transport of glucose. The $\mathrm{NH}_{2-}$ and $\mathrm{COOH}$-terminal regions and the exoplasmic segments are less conserved and may contribute to isoform-specific properties, such as the kinetics, hormone sensitivity, and subcellular localization $(15,16,18-24,26)$.

There are two classification schemes for the family of facilitative glucose transporters. One is based on the order of cloning of the different isoforms and the other is based on the tissue or celltype from which the isoform was first cloned. In this review, we will adhere to the numerical nomenclature. Some characteristics of the different isoforms are compiled in Table 1.

The studies of Bell et al. (13) had revealed similarities in the structures of the human glucose transporter genes. All of their exon-intron orientations are very similar. Glucose transporter (Glut) 1 has 10 exons, whereas Glut 2 and 5 have 11 exons. An additional intron subdivides exon 4 of the Glut 1 gene into two 
Glut 2 exons ( $4 \mathrm{a}$ and b). Similarly, Glut 5 has an additional intron dividing exon 9 into $9 \mathrm{a}$ and $9 \mathrm{~b}$. The length of the genes varies from 8 to $35 \mathrm{~kb}(13)$.

\section{INSULIN-SENSITIVE TISSUES}

Isoform Distribution. The insulin-sensitive tissues, fat and muscle, express the Glut 1 and Glut 4 transporter isoforms (22, 27-29). Glut 4 is at least 10-fold more abundant in fat and skeletal muscle than is Glut $1(22,27,28,30)$. Immunolocalization studies in skeletal muscle indicate that Glut 1 expression is concentrated in the perineural sheath and that Glut 4 is the main muscle cell transporter (31). However, these data do not exclude a lower level of expression of Glut 1 in muscle cells than in nerve. The level of Glut 4 expressed in insulin-sensitive tissues of the rat (brown fat $>$ heart $>$ red muscle $>$ white muscle $>$ white fat) parallels the magnitude of the insulin-mediated increase in glucose transport observed in these tissues (22). This suggests that Glut 4 is the isoform primarily responsible for acutely insulin-stimulated glucose transport.

Insulin. Insulin rapidly increases glucose uptake and metabolism in fat and skeletal muscle (32-34). This response, especially in skeletal muscle, is crucial to lowering blood glucose levels in the postprandial state. Transport is rate-limiting for glucose metabolism in these tissues $(35,36)$ and, thus, insulin exerts its stimulatory effect principally via increasing this initial step in glucose uptake. The cellular mechanism of this effect has been studied most thoroughly in adipocytes $(27,28,37-43)$. In the basal state, both Glut 1 and Glut 4 are concentrated in an intracellular storage pool $(38,39)$. This storage pool corresponds to tubulo-vesicular elements of the trans-Golgi reticulum $(40$, 41). Essentially all of the Glut 4 is present in intracellular compartments in the basal state, but a proportion of Glut 1 is found in the plasma membrane, where it likely contributes to the low level of basal transport observed in these cells $(28,42$, 44).

Insulin induces the redistribution of both Glut 1 and Glut 4 from their intracellular storage sites to the cell surface, resulting in augmented glucose transport $(27,28,42,44)$. This effect occurs within minutes and is rapidly reversible upon insulin withdrawal. Although there is some controversy concerning this point, it appears that most of the insulin-stimulated increase in glucose transport in adipocytes can be attributed to this translocation phenomenon $(28,41,42)$. Ultrastructural studies suggest that a similar translocation mechanism exists in skeletal muscle (45).

In addition to its acute effect on glucose transport, insulin alters transporter gene expression after prolonged exposure of insulin-sensitive cells. Chronic treatment of rats with insulin results in an increase in total adipocyte glucose transporters as measured by cytochalasin B-binding (46). This is solely due to an increase in Glut 4 (47). Chronic insulin-induced hypoglycemia in rats results in an increase (48) or decrease (49) in skeletal muscle Glut 4 protein, depending on the treatment protocol, with little or no change in Glut 1.

Interpretation of in vivo studies involving alterations in insulin levels is complicated by the occurrence of secondary effects, e.g. changes in blood glucose or other circulatory factors. Thus, it is not possible to determine the direct mediator of the changes in glucose transporter gene expression from these experiments. However, the effect of insulin on transporter gene expression has also been studied in cultured cells whose environment can be more precisely manipulated. Insulin increases glucose transport via a selective increase in Glut $1 \mathrm{mRNA}$ and protein in 3T3L1 adipocytes (50). The level of total cellular Glut 4 is unchanged by chronic insulin exposure, whereas the amount of Glut 4 on the cell surface actually decreases (51). Apparently, the increase in total cell-surface Glut 1 due to de novo protein synthesis is sufficient to compensate for the decrease in Glut 4, resulting in an overall increase in transport activity.

The extracellular glucose concentration also affects glucose transport activity and transporter gene expression in 3T3L1 adipocytes (52). Glucose withdrawal increases transport activity via a complicated series of events involving a pretranslational increase in Glut 1 expression and translocation of preexisting intracellular Glut 4 to the plasma membrane. Interestingly, the level of total cellular Glut 4 protein remains unchanged after 3 $\mathrm{d}$ of glucose withdrawal despite a dramatic reduction in the Glut $4 \mathrm{mRNA}$ level. This suggests that glucose starvation enhances the stability of Glut 4 protein in the plasma membrane.

Exposure of L6 myocytes to insulin for $24 \mathrm{~h}$ increases glucose transport and results in a selective increase in Glut 1 gene expression (53). Glut 4, under these conditions, is down-regulated at the level of the mRNA. The level of Glut 4 protein increases in the plasma membrane and decreases in intracellular membranes. Apparently, translocation of preexisting intracellular Glut 4 to the plasma membrane occurs concomitant with a suppression in de novo Glut 4 synthesis. Glucose starvation of L6 cells results in an increase in transport activity accompanied by a pretranslational increase in Glut 1 expression, and an increase in Glut 4 protein with no change in Glut 4 mRNA (54). It is difficult to evaluate the contribution of each transporter isoform to total transport activity in L6 cells, because the absolute or relative level of expression of the two isoforms in these cells has not been reported.

Thus, in adipocyte and muscle cell lines, both insulin and glucose directly modulate glucose transporter gene expression. Chronic insulin treatment most likely increases glucose transport by stimulating the synthesis of Glut 1 , with little or no effect on Glut 4 expression. This contrasts sharply with the long-term in vivo treatment of rats with insulin, in which alterations in Glut 4 levels are observed in fat and muscle tissue with little or no change in Glut 1 (46-49). This apparent discrepancy could be due to secondary changes that occur in vivo in response to insulin administration or to genuine differences between the response of the cultured cell lines and their tissues of origin. The resolution of this disagreement will depend on additional gene expression

Table 1. Mammalian facilitative glucose transporters

\begin{tabular}{|c|c|c|c|c|}
\hline Name & $\begin{array}{c}\text { Numerical } \\
\text { nomenclature }\end{array}$ & Tissue distribution & Kinetic properties & $\begin{array}{r}\text { Location of } \\
\text { human gene }\end{array}$ \\
\hline HepG2 & Glut 1 & $\begin{array}{l}\text { Many adult and fetal tissues, abundant in } \\
\text { human red cells, placenta, brain } \\
\text { microvessels }\end{array}$ & $\begin{array}{l}\text { Erythrocyte: asymmetric carrier with exchange } \\
\text { acceleration; Km } \sim 5-30 \mathrm{mM} \text { (variable); } \mathrm{V}_{\max } \\
\text { (influx) }<\mathrm{V}_{\max } \text { (efflux) }\end{array}$ & $1 \mathrm{p} 35 \rightarrow 31.3$ \\
\hline Liver & Glut 2 & Liver, pancreatic $\beta$-cells, kidney, intestine & $\begin{array}{l}\text { Liver: simple, symmetric carrier; } \mathrm{Km} \sim 60 \mathrm{mM} \text {; } \\
\text { Intestine: asymmetric carrier; } \mathrm{V}_{\max } \text { (efflux) }< \\
\mathrm{V}_{\max } \text { (influx) }\end{array}$ & $3 \mathrm{q} 26$ \\
\hline Fetal muscle & Glut 3 & $\begin{array}{l}\text { Many adult and fetal tissues, abundant in } \\
\text { placenta, brain, kidney }\end{array}$ & Exchange $\mathrm{Km} \sim 10 \mathrm{mM}$ & $12 \mathrm{p} 13$ \\
\hline Fat/muscle & Glut 4 & $\begin{array}{l}\text { White and brown fat, skeletal muscle, } \\
\text { heart }\end{array}$ & $\begin{array}{l}\text { Adipocyte: simple, symmetric carrier; } \mathrm{Km} \sim 2-5 \\
\mathrm{mM}\end{array}$ & $17 \mathrm{p} 13$ \\
\hline Intestine & Glut 5 & Jejunum, fat, kidney & $?$ & $1 \mathrm{p} 31$ \\
\hline
\end{tabular}




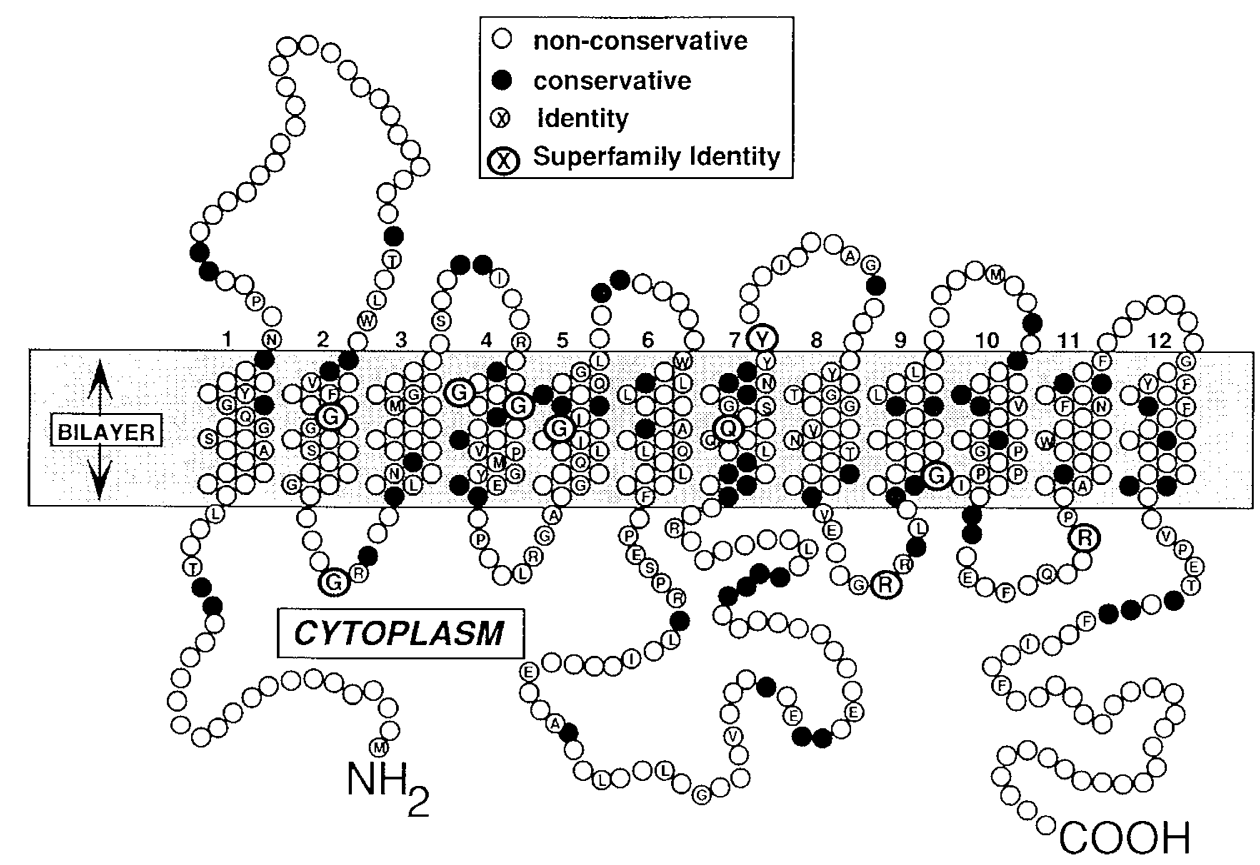

Fig. 1. Predicted topology of the mammalian facilitative glucose transporters. Based on the model proposed in Reference 15 . The proteins are predicted to span the membrane in the form of $12 \alpha$-helical domains. Residues that are nonconserved among the five known mammalian transporter isoforms are shown as open circles. Conserved residues are shown as closed circles. The single letter amino acid code is used to indicate residues that are identical among the five mammalian isoforms. Residues that are identical among members of the Sugar Transporter Superfamily are shown as larger circles.

studies and, perhaps, characterization of regulatory elements within the glucose transporter genes.

Counter-Regulatory Factors. Counter-regulatory factors are those hormones and other agents that oppose the action of insulin on glucose homeostasis. $\beta$-Adrenergic agonists are a classic example of this class of hormone $(55,56)$. At least some of the effects of $\beta$-adrenergic agonists on glucose homeostasis occur at the level of transport. Isoproterenol has been reported to decrease adipocyte glucose transport by affecting a change in the intrinsic activity of glucose transporters without altering their total cellular content $(37,57)$. Isoproterenol inhibits insulin-stimulated glucose transport by $40 \%$ and stimulates phosphorylation of Glut 4 2-fold, without affecting its subcellular distribution in either the basal or the insulin-stimulated state (58). Phosphorylation of Glut 4 by isoproterenol is mediated by an increase in intracellular cAMP, because cAMP analogues mimic the effect (58). These data suggest that Glut 4 phosphorylation may decrease the intrinsic activity of this isoform. The phosphorylation of Glut 4 is confined to a serine/threonine residue in the cytoplasmic carboxy-terminal domain of the protein (59). Studies using okadaic acid, a phosphatase inhibitor, suggest that phosphorylation of Glut 4 may also be involved in triggering the internalization of cell-surface Glut 4 molecules (60). Glucagon, another hormone that increases intracellular cAMP (61) and decreases glucose transport, may also alter glucose transporter intrinsic activity in addition to affecting glucose transporter translocation to the adipocyte plasma membrane (62). The effect of glucagon on Glut 4 phosphorylation as well as the cAMP dependence of its effect on glucose transport have not been reported.

In contrast to the acute inhibitory effect of cAMP on glucose transport in primary rat adipocytes, a marked stimulation of glucose transport into 3T3L1 adipocytes has been reported in response to long-term cAMP exposure $(61,63)$. A $70 \%$ decrease in Glut 4 mRNA and protein occurs in 3T3L1 adipocytes after $16 \mathrm{~h}$ of cAMP exposure. Expression of Glut $1 \mathrm{mRNA}$ and protein increases 3-fold after $6 \mathrm{~h}$ of cAMP treatment. These changes are accompanied by an increased basal 2-deoxyglucose uptake and a loss of insulin-stimulated glucose uptake. Although cAMP has no detectable effect on the fractional distribution of Glut 4 protein between the plasma membrane and low-density microsomes, it causes a substantial increase in the fraction of Glut 1 protein at the plasma membrane. The magnitude of Glut 4 depletion versus Glut $1 \mathrm{mRNA}$ accumulation is cAMP dosedependent, the former being due to a decrease in the transcriptional rate alone, while the latter is secondary to a transient transcriptional activation and mRNA stabilization (61). Whether 3T3L1 adipocytes behave differently than primary rat adipocytes, or whether cAMP exerts opposing effects based on the duration of exposure, is not resolved by these studies. The 3T3L1 adipocytes express less Glut 4 and more Glut 1 than do primary rat adipocytes and, thus, subtle effects on Glut 4 intrinsic activity may go undetected in 3T3 $\mathrm{L} 1$ adipocytes because of the opposing action on the expression of Glut 1 .

Growth hormone is known to produce insulin resistance after prolonged therapy $(64,65)$. Recent investigations demonstrate that, in the basal state, growth hormone suppresses adipocyte Glut 1 expression at a pretranslational level with no effect on Glut 4. Thus, over a period of time, cellular glucose transport is impaired (66).

Steroids, another class of counter-regulatory hormone, alter the insulin-induced recruitment of glucose transporters to the cell surface $(67,68)$ and decrease Glut 4 expression at the mRNA level (69). Acute and chronic exposure of primary rat adipocyte cultures to dexamethasone leads to a decline in both basal and maximally insulin-stimulated glucose transport. Acute (2-h) exposure of adipocytes to dexamethasone results in a decrease in basal and insulin-stimulated cellular plasma membrane glucose transporters without a change in total cellular glucose transporter content. On the other hand, chronic treatment for $24 \mathrm{~h}$ led to depletion of total cellular glucose transporters in both the basal and insulin-stimulated states (69). These alterations may explain some of the steroid-induced perturbations in glucose homeostasis observed in vivo.

Thyroxine increases basal glucose uptake in humans $(70,71)$ and rats (72). Specific studies using the insulin clamp, however, demonstrated no change in basal glucose metabolism, with an increase in insulin-stimulated glucose disposal in hyperthyroid patients (73). The major route of insulin-stimulated glucose 
disposal in hyperthyroid patients appears to be glucose oxidation (73). This may account for decreased skeletal muscle glycogen content in hyperthyroid animals (74). A recent report suggested the mechanism for these changes to be a thyroxine-induced increase in skeletal muscle Glut 4 protein $(75)$. However, the effect of thyroxine on the subcellular distribution of Glut 4 was not examined. Based on these observations, it is possible that an increase in Glut 4 could mediate an increase in insulin-stimulated transport in skeletal muscle, thereby facilitating increased glucose oxidation.

Exercise. Physical training in humans and animals enhances insulin sensitivity in vivo and has been advocated as an adjunct therapy for diabetes (76-80). Acute exercise increases glucose uptake in perfused rat hind limb and isolated skeletal muscle $(81,82)$. This stimulation persists after muscle contraction (82) and can be reproduced by electrical stimulation in vivo (83-85). Acute exercise induces the recruitment of intracellular Glut 4 to the cell surface with no change in the distribution of Glut 1 (86). However, the exercise-sensitive Glut 4 does not appear to originate from the insulin-sensitive intracellular compartment, suggesting the existence of two distinct intracellular pools of recruitable glucose transporters (86). These studies demonstrate that skeletal muscle glucose transport increases with exercise.

Apart from the short-term studies, prolonged exercise training has been shown to enhance the ability of insulin to stimulate glucose uptake into skeletal muscle. A prolonged exercise program of $6 \mathrm{wk}$ duration results in an increase in the rat plantaris (slow-twitch oxidative fibers) Glut 4 protein, with no significant change in soleus (fast-twitch glycolytic and fast twitch oxidative glycolytic fibers), despite a noticeable hypertrophy of the soleus (87). Thus, in certain muscle types, exercise increases the efficiency of the glucose transport system by increasing the total number of insulin-regulatable glucose transporters. On the other hand, chronic physical inactivity caused a decrease in the gastrocnemius muscle growth, glucose uptake, and total glucose transporters as assessed by cytochalasin B binding (88). Although data on the effect of exercise on insulin sensitivity and glucose homeostasis exist for human subjects (76), studies characterizing the effect of either exercise or physical inactivity on human adipocyte or skeletal muscle Glut 4 have not yet appeared.

Abnormal States. Diabetes mellitus. A number of studies have addressed the effect of non-insulin-dependent diabetes mellitus (NIDDM) in the human and streptozotocin-induced diabetes in the rat on glucose transport. Streptozotocin-induced diabetes in the rat is brought about by selective destruction of pancreatic $\beta$ cells, resulting in markedly impaired insulin secretion and insulin resistance in peripheral tissues (89). This metabolic state results in a suppression of insulin-stimulated cellular glucose transport in adipocytes (32). Long-term streptozotocin treatment induces a pretranslational suppression of adipocyte and skeletal muscle Glut 4 with minimal effect on Glut 1 (90). However, milder streptozotocin treatment was reported to decrease adipocyte Glut 4 protein, with no effect on skeletal muscle Glut 1 and Glut 4 protein despite a decrease in the insulin-stimulated glucose uptake (31).

The regulation of Glut 4 in muscle in response to streptozotocin treatment appears to be fiber-type dependent. A week of streptozotocin-induced diabetes results in a significant decline in insulin-stimulated glucose transport in the soleus (type I fibers), pooled deep red quadriceps/gastrocnemius muscles (type I and IIA, slow twitch oxidative fibers), and pooled superficial white quadriceps/gastrocnemius muscles (type IIB, fast twitch glycolytic fibers) (91). A corresponding decrease was noted in red and soleus muscle Glut 4 mRNA and protein, but a significantly diminished down-regulation of Glut 4 was observed in white muscle (91). The physiologic consequences of this regulation may reflect the distinct metabolic properties of these different muscle fibers. It was proposed that diabetes induces a rapid uncoupling of the insulin-stimulated glucose transport system before down-regulating Glut 4 protein and mRNA (91). These changes may be time-dependent, with sequential defects consisting of either impaired skeletal muscle glucose transporter translocation or intrinsic activity, followed by a decline in Glut 4 protein levels, which may contribute toward the insulin-resistant state of type II diabetes (31).

Adipocytes isolated from human NIDDM subjects exhibit decreased insulin-stimulated glucose transport, decreased total cellular transporters as measured by cytochalasin B binding, decreased insulin-induced translocation of intracellular transporters to the plasma membrane, and a pretranslational suppression of Glut 4 expression $(92,93)$. Insulin-mediated glucose uptake into leg muscles is decreased in NIDDM patients when compared with lean and obese controls (94). Pederson et al. (95) reported no difference in the level of Glut 4 in vastus lateralis muscle of diabetics versus controls, whereas Dohm et al. (96) reported a decrease in Glut 4 in rectus abdominis and vastus lateralis in obese insulin-resistant diabetics and nondiabetics relative to nonobese controls. Further studies are clearly necessary to resolve these differences. It is possible that the patient populations in the two studies represented subgroups with distinct characteristics.

Insulin therapy of streptozotocin-treated diabetic rats normalizes the defective insulin-stimulated translocation of intracellular glucose transporters to the cell surface in adipocytes (32). Insulin therapy of greater than $7 \mathrm{~d}$ duration causes an initial overcompensation, resulting in a pretranslational increase above control in Glut 4 expression followed by a return to the prediabetic control level (90). Insulin-induced normalization of Glut 4 expression occurs in both adipocytes and skeletal muscle of streptozotocin-treated diabetic rats $(31,91)$. Although insulin therapy alone reverts Glut 4 expression back to normal, the correction of hyperglycemia per se by increasing renal tubular excretion of glucose by phlorizin administration fails to revert Glut 4 gene expression back to the normal prediabetic state (97). A change in Glut 4 intrinsic activity was proposed as a mechanism for correcting the diabetic hyperglycemia-induced decrease in cellular glucose transport (97). However, it should be noted that phlorizin is a toxin, and its effects on the animal are almost certainly not limited to reversal of hyperglycemia.

Sulfonylureas are oral hypoglycemic agents that are used in the treatment of NIDDM (98). These drugs increase the secretion of insulin from the pancreas $(99,100)$ and also appear to augment glucose disposal in peripheral tissues by a mechanism unrelated to their effect on insulin secretion $(102,102)$. The mechanism of the so-called extrapancreatic effects of the sulfonylureas may involve an alteration in glucose transport. Glyburide appears to have no effect on glucose transport in basal primary rat adipocytes, but enhances the insulin-induced recruitment of intracellular glucose transporters to the cell surface (103). Tolazamide enhances insulin-stimulated glucose transport into L6 rat skeletal muscle cells by increasing the expression of Glut 1 (104). Similarly, tolbutamide increases glucose uptake into 3T3Ll adipocytes by selectively increasing Glut 1 expression with no effect on the steady state level of Glut $4(50)$. Thus, it is feasible that part of the hypoglycemic action of these drugs in vivo is the result of their effects on glucose transport in tissues expressing Glut 1.

Vanadate, a trace element, is a potent insulin-mimetic agent that normalizes hyperglycemia (105). Unlike the effect of sulfonylureas in cultured cells, but similar to that of insulin in whole animals, vanadate acts to relieve diabetic hyperglycemia by inducing expression of skeletal muscle Glut 4 at a pretranslational level (106).

Obesity. Glucose transport is markedly impaired in tissues from obese humans (107) and animals (108). Glut 4 has been extensively studied in this abnormal metabolic state. Relative to its lean littermates, the spontaneously obese, hyperglycemic, hyperinsulinemic, and insulin-resistant $\mathrm{db} / \mathrm{db}$ mouse exhibits decreased Glut $4 \mathrm{mRNA}$ levels in skeletal muscle (quadriceps) but normal levels in other insulin-sensitive tissues (29). However, the level of Glut 4 protein is unaffected in all the insulin-sensitive 
tissues, suggesting that an alternate mechanism is involved in the inhibition of insulin-stimulated glucose disposal in these animals (29). Goldthioglucose-induced obese mice expressing hyperinsulinemia and slight hyperglycemia at 4 to 6 mo of age exhibit a decrease in brown and white adipose tissue Glut 4 protein, with no change in skeletal muscle Glut 4 protein (109). An 18-d treatment with a thermogenic agent, BRL $26830 \mathrm{~A}$, which normalizes blood glucose without affecting the hyperinsulinemia of the obese state, results in an increase in brown and white adipose tissue Glut 4 protein close to lean controls, with no change in skeletal muscle Glut 4 (109). Consistent with this observation is a report describing the effect of $4 \mathrm{~d}$ of hyperinsulinemia with accompanying hypoglycemia or glucose-clamped euglycemia on lean, heterozygous, Zucker rats (49). Similar alterations in Glut 4 expression were observed in both hyperinsulinemic groups when compared with the control group. Hyperinsulinemia of a short duration caused a differential tissue response, with an increase in white adipose tissue Glut $4 \mathrm{mRNA}$ and protein and a decrease in skeletal muscle Glut 4 mRNA and protein.

Collectively, these studies indicate that there is no simple relationship between blood glucose/insulin levels and expression of the major insulin-responsive glucose transporter in fat and muscle. This could be, in part, due to the fiber-type specificity of Glut 4 regulation in muscle, effects on gene expression that change with time, and differences in the response of genetically distinct groups of animals used in the different experiments. It should also be noted that the direct physiologic mediator(s) of the alterations in glucose transporter expression associated with perturbations in glucose and insulin homeostasis in vivo has not been identified. In the context of obesity, these studies suggest that high circulating insulin levels may be responsible for diverting glucose utilization from skeletal muscle into adipose tissue, resulting in obesity. Once a larger white adipose tissue mass is established, an insulin-resistant state sets in with decreased activity of the adipocyte transport system.

Obesity in humans results in impaired insulin-mediated translocation of glucose transporters in adipocytes (92), along with a decrease in adipocyte Glut 4 mRNA and protein relative to lean controls (94). Pederson et al. (95) reported no change in Glut 4 expression in vastus lateralis muscle of obese patients compared to lean controls, whereas Dohm et al. (96) observed a decrease in Glut 4 in rectus abdominis and vastus lateralis muscle of obese patients relative to lean controls. The reason for this discrepancy is not known, but it may relate to the extent of obesity as assessed by the body mass index or some other distinct characteristic of the patient groups used in the two studies.

Starvation. Starvation induces a state in which insulin-stimulated glucose transport into adipocytes is diminished, while insulin hyperresponsiveness is observed in skeletal muscle (34, 110). Insulin resistance in adipocytes is due to a decrease in the total intracellular pool of glucose transporters and to a diminished translocation of glucose transporters from the intracellular pool to the cell surface (110). A decrease in Glut 4 and, to a lesser degree, in Glut $1 \mathrm{mRNA}$ and protein occurs in adipocytes after 2-4 d starvation $(34,111,112)$. A similar state of starvation results in an increase in skeletal muscle Glut 1 and Glut 4 mRNA and protein $(34,48)$. The differential effect on adipose and skeletal muscle Glut 4 during starvation is opposite from that observed in the case of obesity (see above) (49). Refeeding for a period of 6-8 d results in an increase in insulin-stimulated transport in adipocytes that overshoots the control values (34). Refeeding reverses the starvation-induced changes in adipose and muscle Glut 1 and Glut 4 gene expression (34).

Similar studies have not been conducted in humans. Based on the rat investigations, it appears that acute starvation results in a self-preservation phenomenon in which insulin responsiveness is maintained in skeletal muscle. However, prolonged starvation ultimately leads to an insulin-resistant state in vivo $(113,114)$.

Other insulin-resistant states. Other insulin-resistant states that have been studied include high fat/low carbohydrate feeding
(115) and aging (108), where a basal intracellular depletion of glucose transporters, along with a diminished insulin-stimulated translocation of glucose transporters to the adipocyte plasma membrane, were observed. Aging is associated with a decrease in adipocyte Glut 4 protein with no change in Glut $1(116,117)$. An insulin-resistant chronic uremic state was examined in partially nephrectomized rats (118). Both basal and insulin-stimulated glucose transport into isolated adipocytes were decreased because of a decline in total cellular glucose transporters and a resultant diminution in insulin-induced translocation to the cell surface.

Development and Cellular Differentiation. The most prominent fetal glucose transporter is Glut 1 , which is expressed by almost all fetal tissues examined, including those tissues that fail to express it significantly in the adult. Most fetal cells exhibit rapid growth and development necessitating an enhanced requirement for various metabolic substrates, including glucose. This is not unlike cellular growth observed in vitro (119). Thus, ontogenic studies in most tissues have revealed a higher expression of Glut 1 in fetal tissues when compared with the corresponding neonatal and adult tissues $(120,121)$. On the other hand, fetal tissues are more resistant to the acute metabolic action of insulin when compared with the adult (122). Of the different insulin-responsive tissues, skeletal muscle and heart have been examined in the fetal rat $(120,121)$. In skeletal muscle, a higher molecular mass fetal form $(\sim 50-55 \mathrm{kD})$ was observed in addition to the lower molecular mass adult form ( 45-50 kD) (120). The significance of the two forms in fetal tissues is not clear, because it reportedly cannot be explained by glycosylation differences alone (120). However, preliminary observations from our laboratory are highly suggestive of red cells within vascular spaces of fetal tissues contributing to the increased abundance of the Glut 1 isoform in certain tissues at this developmental stage (123). Thus, studies using whole tissues may not be able to distinguish between the fetal red cell and the tissue-specific Glut 1 transporter. In contrast, Glut 4, which is abundant and vital to the adult insulin-responsive tissues, is expressed at a much lower abundance in the fetus (our unpublished observations) and preweaning newborn (124). Thus, it appears that although basal glucose requirements necessary for cellular growth and proliferation are high in the fetus, the specialized insulin-responsive glucose transport needs do not develop until later in life.

The neonatal period is a transitional stage during which various changes in glucose metabolism take place. Glut 1 tends to decline in most tissues examined during the early neonatal period and either remains low in the adult or increases again in the young adult, depending on the tissue (121). Glut 4 increases in adipocytes and skeletal muscle during the stage of weaning to reach adult levels by a few weeks of age (124). Investigations designed to determine the factors that regulate this developmental increase in the expression of glucose transporters in insulin-responsive tissues are limited. A recent report suggested that weaning from a high-fat milk diet to a high-carbohydrate diet is a critical factor in inducing Glut 4 expression in both adipocytes and skeletal muscle, thereby conferring insulin sensitivity at the age of weaning (124).

The expression of Glut 1 and Glut 4 has been examined during the differentiation of $3 \mathrm{~T} 3 \mathrm{~L} 1$ cells from the fibroblast-like preadipocytes to the adipocyte stage $(50,125)$. The preadipocytes express only Glut 1. During differentiation, the level of Glut 1 progressively decreases concomitant with the appearance and increased expression of Glut 4. The decrease in Glut 1 parallels a decrease in basal transport activity in the differentiating cells, whereas the increase in Glut 4 parallels the increase in insulinstimulated transport activity. The turn-on of Glut 4 expression is likely mediated by the nuclear transcription factor, CCAAT/ enhancer binding protein (C/EBP) (125).

Genetics. The glucose transporters of insulin-sensitive tissues (22) are logical targets for genetic defects predisposing to insulinresistance $(92,93,95,96)$. The detection of restriction fragment 
length polymorphisms in the Glut 1 and Glut 4 genes has led to genetic linkage studies involving NIDDM populations. Positive associations between polymorphisms at the Glut 1 locus and NIDDM have been reported in some racial groups (126), but not in Afro-Americans $(127,128)$ or Chinese Americans (129). Glut 4 cDNA clones were also used to evaluate DNA polymorphisms in genomic DNA from American blacks with NIDDM (130). A single polymorphism was identified. However, the allelic, genotypic, and haplotypic frequencies of the DNA polymorphism did not differ in frequency between diabetic and control populations. It appears unlikely that specific alleles at the Glut 1 and Glut 4 genes contribute in a major way to the genetic susceptibility to NIDDM observed in Afro-Americans. However, these data do not exclude the possible involvement of these genes in the predisposition to insulin-resistance of NIDDM in a subpopulation of diabetics.

\section{LIVER AND PANCREATIC $\beta$-CELLS}

Isoform Distribution. Glut 2 is the major transporter isoform expressed in hepatocytes and $\beta$-cells of the pancreatic islets (1820). Perivenous hepatocytes do express detectable levels of Glut 1 (131). Glut 2 appears to be a high-turnover/low-affinity transporter (132). Transport is not rate-limiting for glucose uptake into either $\beta$-cells or hepatocytes, and the intracellular sugar concentration approaches the extracellular concentration (14, 133). This is in sharp contrast to the situation in muscle and fat cells, where transport is clearly rate-limiting for glucose metabolism $(35,36)$. The high $\mathrm{Km}$ exhibited by Glut 2 in these tissues may reflect the fact that splanchnic tissues can be exposed to a higher glucose concentration than is present in peripheral blood. The operation of this transport system at low substrate concentrations relative to its $\mathrm{Km}$ suggests that the rate of transport should vary linearly with the sugar concentrations (14). This is a desirable situation for both the hepatocytes and the $\beta$-cells. The rate of glucose transport into hepatocytes will thus increase when portal blood sugar rises in the postprandial state, ensuring that transport does not limit the net uptake and storage of excess glucose (14)

$\beta$-Cells are essentially glucose homeostats that are designed to react to changes in blood glucose by varying their rates of insulin biosynthesis and secretion. A high-Km transporter in this celltype ensures accurate sensing of blood glucose levels $(20,133)$. Interestingly, in rat islets, Glut 2 is concentrated in those regions of the $\beta$-cell membrane that face other endocrine cells rather than membrane surfaces that face blood capillaries (134). The functional significance of this is not known, but perhaps Glut 2 is involved in the transcellular flux of glucose through $\beta$-cells, directing it to regions distal to blood capillaries.

Abnormal States. Diabetes mellitus. Streptozotocin-induced diabetes results in an increase in liver Glut $2 \mathrm{mRNA}$ levels in the rat $(135,136)$. Conversely, underexpression of Glut 2 was reported in pancreatic islets of the Zucker diabetic fatty rat compared to its lean littermates (137). It was proposed that the decrease in islet Glut 2 is responsible for the diminished glucosestimulated insulin secretion observed in these animals. Similarly, in the case of new onset autoimmune diabetes mellitus in the $\mathrm{BB} /$ Wor rat, a reduction in Glut 2 expression paralleled the loss of glucose-stimulated insulin secretion that usually precedes profound $\beta$-cell depletion (138). However, unlike the situation in adipocytes and skeletal muscle, transport is not rate-limiting for islet or liver glucose metabolism $(14,133)$ and, thus, the functional consequences of these changes, if any, is not known.

In distinct contrast to the state of diabetes, prolonged hyperglycemia alone in the presence of a normal pancreas results in an increase in the rat $\beta$-cell Glut 2 mRNA by $46 \%$, along with an increase in proinsulin expression (139). Thus, under different conditions, $\beta$-cell Glut 2 expression seems to parallel insulin secretory function. However, it is unclear, at present, whether this correlation represents any type of cause-and-effect relationship between these two parameters.

The serum of insulin-dependent diabetic human subjects has been reported to contain an IgG directed against $\beta$-cell Glut 2 (140). Although a controversial finding, this $\mathrm{IgG}$ reportedly inhibits glucose transport into rat $\beta$-cells and, thereby, impairs glucose-stimulated insulin secretion.

Starvation. Perivenous hepatocytes in normal rat liver express Glut 1 , whereas the remaining hepatocytes express primarily the Glut 2 isoform (131). During starvation, a 3- to 4-fold increase in the expression of Glut 1 was observed in these cells. The increase correlated with the expression of Glut 1 in an increased number of hepatocytes. The increased expression of Glut 1 was reversed after glucose refeeding (131). Similar experiments examining Glut 2 expression showed that $2 \mathrm{~d}$ of fasting decreases Glut 2 mRNA by $45 \%$ and 24 -h refeeding increases Glut 2 mRNA levels 5-fold. Starvation did not affect the level of Glut 2 protein in liver; however, refeeding increased the level of Glut 2 protein $75 \%$ above the prestarvation control level (136).

Hypoglycemia. The effect of insulin-induced hypoglycemia on glucose transporter gene expression has been studied in both the liver and pancreas (139). Although a significant reduction in Glut $2 \mathrm{mRNA}$ in pancreatic islet $\beta$-cells was observed along with a decrease in proinsulin mRNA, a relatively slight reduction occurs in liver Glut 2 mRNA. These results are consistent with an adaptive response in which hypoglycemia results in a diminished pancreatic secretion of insulin, but not necessarily a diminished output of hepatic glucose. However, the actual physiologic consequences of these changes in Glut 2 expression are not known.

Normal Development. Glut 1 appears to be the predominant glucose transporter isoform expressed in fetal liver $(120,121)$. Although specific studies determining the presence of Glut 2 in fetal liver have not been reported, D-glucose-inhibitable cytochalasin $\mathrm{B}$ binding has been studied in rabbit liver. Fetal liver possesses fewer low-affinity (Glut 2) (141) sites compared to that of the adult (142). These findings along with reports on the abundance of Glut 1 in fetal liver $(120,121)$, suggest that Glut 2 is expressed in negligible amounts at this stage. The neonatal period is a transitional stage during which the newborn begins to rely on endogenous production of glucose via glycogenolysis (143) and gluconeogenesis in the liver (144). In the neonate, liver Glut 1 expression is low, mimicking the adult levels (121), and Glut 2 levels are intermediate between the fetal and adult concentrations (141). The expression of glucose transporter isoforms in $\beta$-cells during ontogeny has not been reported.

Genetics. The detection of restriction fragment length polymorphisms in the human Glut 2 gene has led to genetic linkage studies involving NIDDM populations. Three highly polymorphic sites were identified within the Glut 2 gene, one of which (EcoRI-HaeIII) appeared to be due to an insertion and/or deletion of $200 \mathrm{bp}$ of DNA (130). Significant linkage disequilibrium between these sites over $\sim 30 \mathrm{~kb}$ of genomic DNA suggested that these polymorphisms could be in linkage disequilibrium with mutations at this locus, if they existed. The frequencies of these polymorphisms did not differ between diabetics and controls. Therefore, it appears that mutations at this locus may not contribute in a major way to the genetic susceptibility to NIDDM observed in Afro-Americans (130). Once again, however, the power of these studies is not sufficient to eliminate this locus as a contributor to the NIDDM phenotype in a subpopulation of diabetics.

\section{KIDNEY AND SMALL INTESTINE}

Isoform distribution. A property shared by the kidney, small intestine, and liver is that the net release of glucose from these tissues into the blood can occur under appropriate metabolic situations (14). Although the liver is the principle supplier of blood glucose during short fasts, the kidney can also become a 
net producer of blood glucose during prolonged starvation (145). During the postprandial phase, the small intestine catalyzes the transepithelial flux of glucose into the bloodstream. The initial step of lumen to intracellular transport is accomplished by the sodium-glucose cotransporter that is situated on the lumenal surface of brush border cells of the proximal tubule of the kidney (7-11) and the enterocytes lining the intestinal microvilli (3-6). The second step of transepithelial transport involves the high $\mathrm{Km}$ Glut 2 that is localized to the basolateral membrane of the epithelial cells lining the renal tubules and intestinal microvilli $(146,147)$. Glut 2 is involved in the net release of glucose into the blood during absorption of renal and intestinal glucose, ensuring that the glucose flux across these absorptive cells changes in a near-linear fashion with the intracellular glucose concentrations.

Glut 5 is expressed at high levels in the jejunum, but little is known concerning its function (26). Localization of this isoform to the apical or basolateral surface of specific cell types will facilitate the elucidation of its function. It is tempting to speculate that this isoform may be involved in the transepithelial flux of sugar substrates other than glucose.

Regulation. Few studies are available concerning the regulation of renal and intestinal glucose transporters. Glucose deprivation induces a selective accumulation of Glut 1 protein in the plasma membrane of cultured normal rat kidney cells, thereby increasing glucose transport (148). Streptozotocin-induced diabetes increases the activity of the sodium-glucose cotransporter in rat small intestine by increasing transporter number (149). Insulin therapy normalizes this change, whereas starvation-induced normoglycemia fails to have an effect on the diabetes-induced effect (149).

Normal development and cellular differentiation. The sodiumglucose cotransporter is present at lower abundance in fetal than in adult kidney (150). The glucose transporter system in the intestinal enterocyte is a marker for enterocyte maturity, developing in the fully differentiated cells present only at the tip of the microvillus (3). Developmental regulation of Glut 2 and Glut 5 in the kidney and small intestine has not been reported.

Genetics. The identification of an EcoRI restriction fragmentlength polymorphism within the human sodium-glucose cotransporter gene should facilitate studies investigating the involvement of this sodium-glucose cotransporter in genetic disorders, such as benign renal glycosuria and the glucose-galactose malabsorption syndrome $(12,13)$. Recent studies involving sequence analysis of polymerase chain reaction-amplified sodium-glucose cotransporter cDNA and genomic DNA obtained from members of a family affected with the autosomal recessive glucose-galactose malabsorption syndrome revealed a single missense mutation in the sodium-glucose cotransporter gene. This mutation cosegregates with the glucose-galactose malabsorption phenotype and results in complete loss of sodium-dependent glucose transport in Xenopus oocytes injected with the mutant mRNA (151).

\section{BRAIN}

Isoform distribution. Glucose is an essential substrate for oxidative metabolism in brain (152). Circulating glucose crosses the blood-brain barrier and enters brain parenchymal cells via facilitative transport. The adult mammalian brain expresses Glut 1 and Glut $3(16,21)$. The other facilitative glucose transporters appear to be absent from adult human cerebrum $(18,22-26)$.

In rat and human adult brain sections, Glut 1 is predominantly localized to the brain microvasculature (153-156). Electron microscopic examination revealed $\sim 40 \%$ of Glut 1 on the ablumenal surface of the endothelial cells, with another $40 \%$ in the cellular cytoplasm and $10 \%$ on the lumenal surface (157). A report on the adult rat brain microvasculature suggested that nearly all D-glucose inhibitable cytochalasin B binding sites corresponded to Glut 1 (158). Thus, it appears that in adult rat brain, Glut 3 is not localized to the microvasculature but to brain parenchymal cells (158). Glut 1 and 3 are both expressed in cultured rabbit neonatal glial cells (Figs. 2 and 3) (159). Cultured neonatal neurons, on the other hand, which exhibit a relatively high glucose requirement (160-162), express very low levels of the Glut 1 isoform and no detectable Glut 3 (Figs. 3 and 4) (159). This suggests the possibility of an as yet unidentified neuronal type of glucose transporter during the newborn period. However, inasmuch as cross-species probes were used in these studies, it is possible that the expression of some rabbit glucose transporter isoforms went undetected. Whether a similar cellular distribution of glucose transporter isoforms exists in the adult brain is not known.

Regulatory studies. Hypoglycemia increases and hyperglycemia decreases glucose uptake into adult rat brain $(163,164)$. These changes appear to be due to alterations in Glut 1 gene expression. Streptozotocin-induced hyperglycemia increases Glut 1 mRNA (165) while down-regulating the transporter protein (166) in adult rat brain microvessels. Conversely, insulininduced hypoglycemia increases Glut 1 protein levels in whole rat brain (167). Thus, there appears to be an inverse correlation between blood glucose levels and the expression of Glut 1 in brain microvessels. This may be a compensatory response to

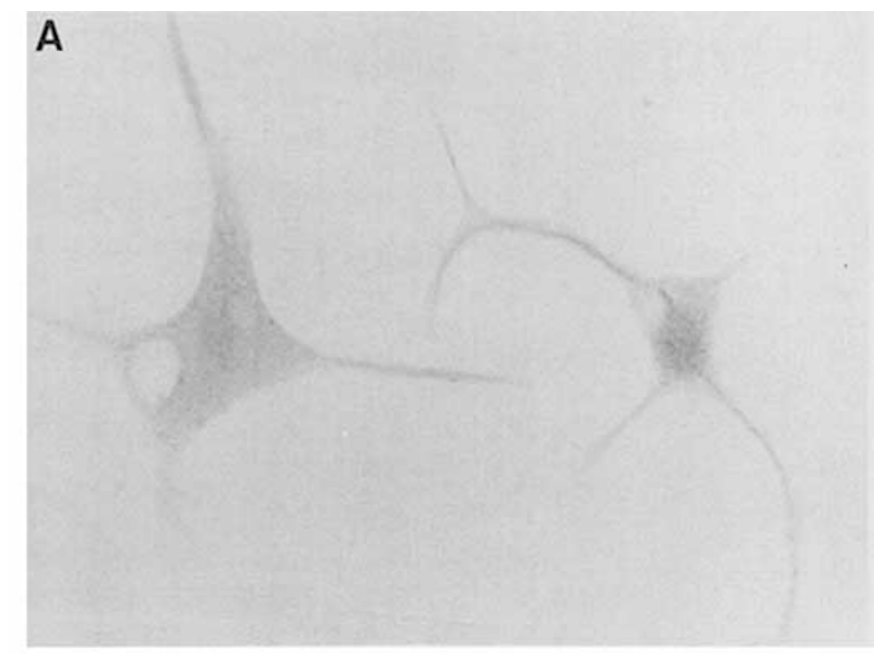

B

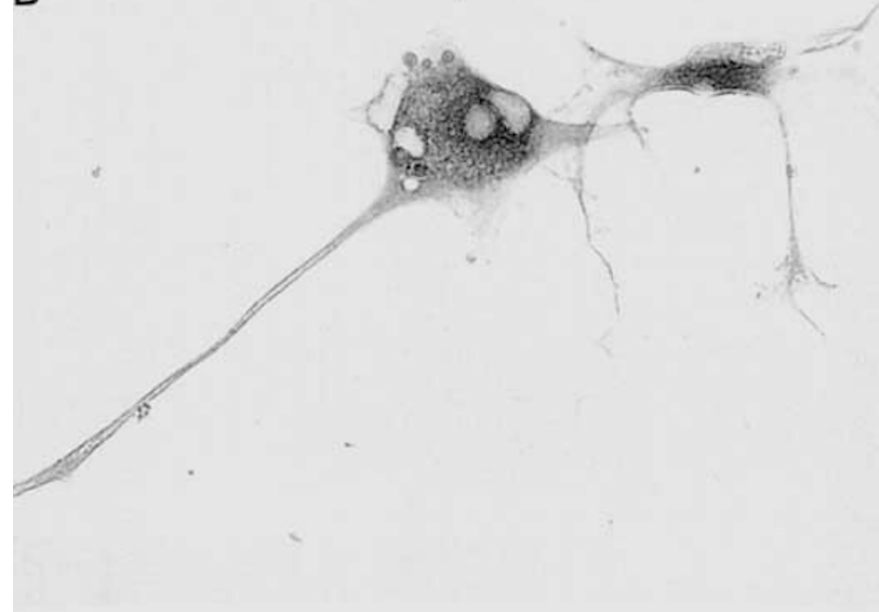

Fig. 2. Immunohistochemistry of rabbit glial cell cultures. $A$, Control treated with a 1:500 dilution of normal rabbit serum/preimmune serum ( $\times 400$ magnification) demonstrating control staining with $3^{\prime}, 3^{\prime}$-diaminobenzadine. $B$, A 1:500 dilution of the anti-rat brain glucose transporter antibody (Ref. 22) ( $\times 400$ magnification) demonstrating the perinuclear cytoplasmic and plasma membrane distribution of the glucose transporter immunoreactivity (Ref. 159). (Reproduced with permission from Williams \& Wilkins, Baltimore, MD, and Plenum Press, New York, NY.) 


\section{A}

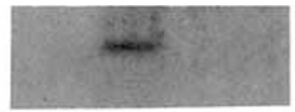
$-45 K-$

\section{G N}

B

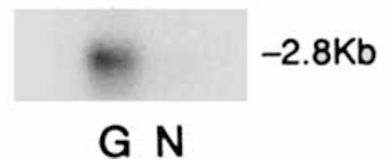

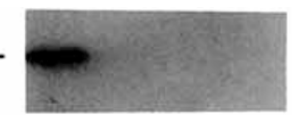

M G N

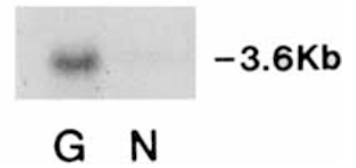

Fig. 3. Autoradiographs of Western blots demonstrating the Glut 1 (left panel) and Glut 4 (right panel) proteins $(\sim 45 \mathrm{kD})$ in muscle $(M)$, glia $(G)$, and neurons $(N)$. B. Autoradiographs of Northern blots demonstrating the Glut $1(\sim 2.8 \mathrm{~kb}$; left panel) and Glut $3(\sim 3.6 \mathrm{~kb}$; right panel) mRNA in glia $(G)$ and neurons $(N)$ (Ref. 159). (Reproduced with permission from Williams \& Wilkins, Baltimore, MD.)

ensure that transport of glucose across the blood-brain barrier does not become rate-limiting for glucose utilization in brain cells during a prolonged decrease in blood glucose levels. Consistent with this hypothesis, in cultured glial cells, Glut 1 protein and mRNA vary inversely with the level of glucose in the medium, i.e. high glucose suppresses Glut 1 expression and glucose starvation increases expression (168). This is similar to the effect of glucose availability on transporter gene expression in 3T3L1 adipocytes (52) and L6 myoblasts (53). The mechanism of the glucose-mediated alterations in glucose transporter gene expression is not known.

Insulin and IGF-I increase glucose transport in isolated glial cells by increasing expression of the Glut 1 gene (169). IGF-I appears to increase Glut 1 expression and glucose uptake only in neonatal rat glial cells, with no such effect in adult cells despite the greater abundance of IGF-I receptors (170).

Normal development. The Glut 1 transporter is developmentally regulated in rat and rabbit brain (121, 159, 171). Its expression is highest in adult brain, followed by fetal and neonatal brain, respectively. This finding is consistent with the observation that glucose transport in adult brain is higher than that in neonatal rat brain $(172,173)$. Detailed examination of Glut 1 protein in fetal rat brain revealed a $55-\mathrm{kD}$ species along with the $45-\mathrm{kD}$ adult form (120). This size difference reportedly cannot be explained by differential glycosylation alone (120). An examination of isolated microvessels from rat brain demonstrated a gradual increase in total glucose transporters, composed mainly of Glut 1 , from the fetal to the adult stage of development (174). Glut 1, which is primarily expressed in brain vasculature at most stages of development, is preferentially expressed in brain parenchymal cells during the neonatal phase of brain development (174). Only Glut 1 and Glut 3 appear to be expressed in the rabbit CNS (159). The ontogenic expression of Glut 3 in rabbit brain follows a reciprocal pattern to that of Glut 1 . The lowest expression is found in the fetal brain, followed progressively by the adult and late neonatal stages (159).

\section{LUNG}

Glucose is an important metabolic substrate in the lung (175). An intricate relationship has been suggested between lung glucose-glycogen metabolism and surfactant phospholipid synthesis (176-178). Circulating glucose enters lung epithelial cells and contributes to pulmonary glycogen $(179,180)$ and, thereby, the glycerol backbone of disaturated phosphatidylcholine $(178,181)$. High circulating glucose results in a derangement of lung phosphatidylcholine synthesis and flux (182), thus causing the clinical syndrome of respiratory distress (183).

Studies defining the glucose transport system in lung are

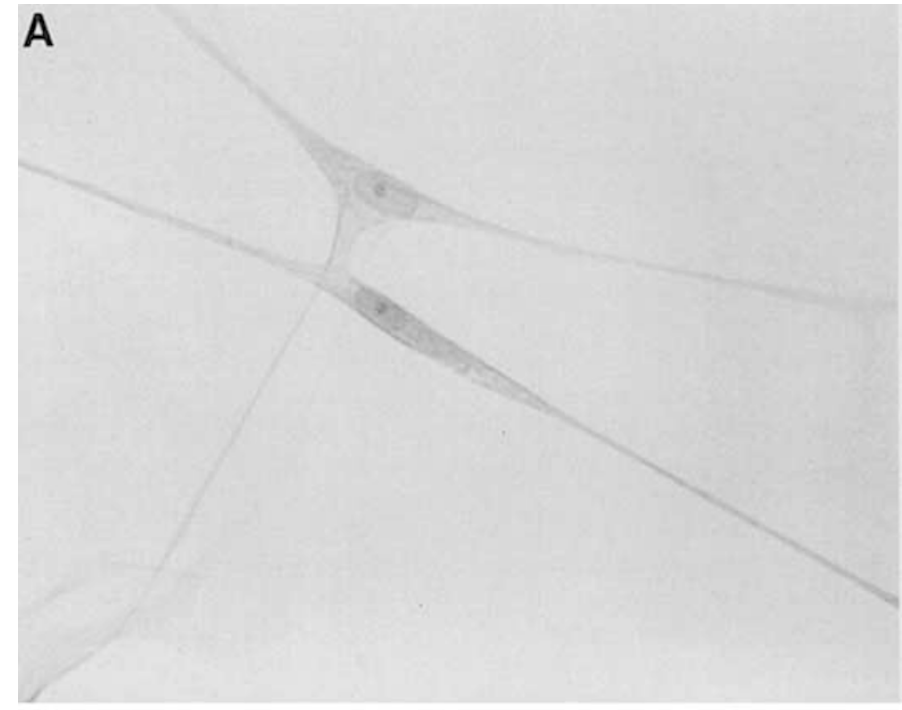

\section{B}

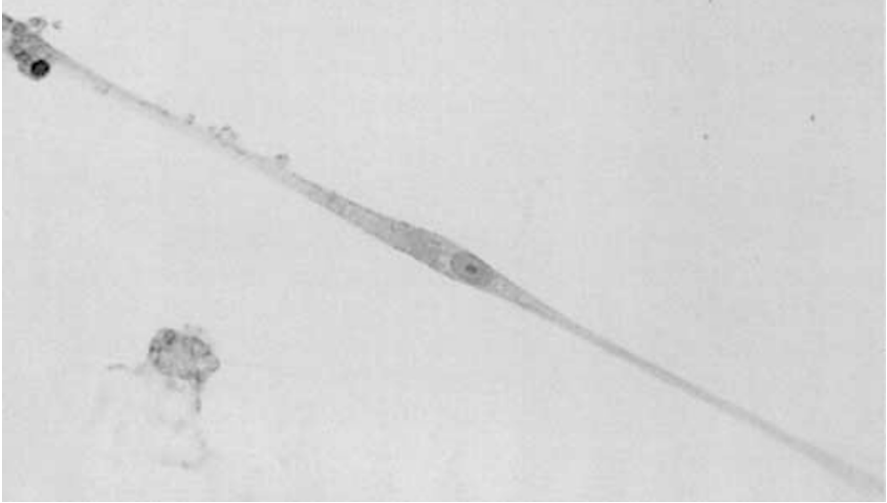

Fig. 4. Immunohistochemistry of rabbit neuronal cell cultures. $A$, Control cultures were treated with a 1:500 dilution of a normal rabbit serum/preimmune serum $(\times 400)$, and the cells were counterstained with hematoxylin. $B, A$ 1:500 dilution of the anti-rat brain glucose transporter antibody demonstrating a rather slight immunoreactivity (above control staining) within the cytoplasm $(\times 400)$ (Ref. 159). (Reproduced with permission from Williams \& Wilkins, Baltimore, MD.)

limited. Glucose within the alveolar lumen is absorbed by the alveolar epithelial cells via a saturable mechanism that is linked to sodium transport $(184,185)$. In confirmation of these observations, the sodium-glucose cotransporter system has been detected in adult rat alveolar cells (186). Thus, in the adult, the sodium-glucose cotransporter may play a role in removing solutes and water from the alveolar spaces (185), but in the fetus its role appears to be insignificant (187). On the other hand, the system involved in transporting glucose from the bloodstream into the alveolar cells is unknown. The presence of a facilitative glucose transport system was detected in adult rat lung type II alveolar epithelial cells maintained in vitro (188). Glut 1 mRNA is abundantly expressed in fetal lung when compared with that of the newborn and adult (121). In mouse lung sections, Glut 1 protein appears to be expressed in fetal red cells, accounting for the greater fetal lung Glut 1 expression, with the alveolar epithelium being distinctly negative (123). In adult mouse lung, Glut 1 is not expressed by either the adult red cells trapped in lung tissue or the alveolar epithelial cells, but is abundant in Schwann cells that form the perineural sheath (123). Thus, the major 
alveolar epithelial cell facilitative transport system remains to be defined.

\section{PLACENTA}

Glucose transport across the placenta is an insulin-independent facilitative diffusion process $(189,190)$. A number of studies have been reported on glucose transport in normal placenta (191). Further, it has been determined that Glut 1 and Glut 3 are the predominant placental isoforms $(13,21)$. Glut 1 is mainly localized to the ectoplacental fenestrated epithelial cells lining the maternal vascular spaces and serving as a materno-fetal barrier (192).

A decrease in the fractional clearance of 3-O-methyl glucose across the placenta was observed in the streptozotocin-induced diabetic pregnant rat model, indicating a decrease in maternofetal transfer of glucose (193). Although other studies have examined the effect of maternal diabetes on placental glycogen metabolism $(194,195)$, there are no studies, to date, describing the placental transport system in a diabetic state.

Intrauterine growth retardation does not affect glucose transport across the placenta in the guinea pig (196) or alter placental glucose utilization in the rat (197). Insulin-induced hypoglycemia in rats also does not change glucose uptake by the placenta (198). Therefore, in the absence of specific studies examining the regulation of placental glucose transporters, it appears that there may be no long-term change in placental glucose transporters as the result of a hypoglycemic insult.

\section{GROWTH AND REGENERATION IN MISCELLANEOUS TISSUES}

Various malignant states are associated with an increased expression of Glut 1 or Glut $3(199,200)$. Liver regeneration, as the result of partial hepatectomy, results in a 2- to 3-fold increase in Glut 2 expression in hepatocytes (201). These observations suggest that normal and abnormal cellular growth result in an increased expression of glucose transporters to increase the supply of glucose for growing and dividing cells. In support of this hypothesis, experiments undertaken in vitro have demonstrated that cells transformed by certain oncogenes ( $s r c$ and ras) (202, 203) and growth factors, such as fibroblast growth factor, epidermal growth factor, platelet-derived growth factor (119), insulin, and insulin-like growth factors $(54,169)$, enhance the expression of Glut 1 and, thereby, increase cellular glucose uptake. Although the intracellular signaling pathway between insulin/IGF-I and the Glut 1 transporter is unknown, in L6 myocytes both of these factors increase Glut 1 transcription and mRNA stability (54).

Phorbol esters increase Glut 1 expression in some cultured cells by activation of protein kinase $C$ (204). Additionally, in nonregenerating cells, phorbol esters phosphorylate Glut 1 and, thereby, covalently modify the protein rather than alter its expression (205). However, the phosphorylation of Glut 1 by phorbol esters is substoichiometric and has no known functional significance.

Tumor necrosis factor, a pluripotent endotoxin-induced macrophage secretory protein, is cytotoxic or cytostatic to many tumor cells. This monokine, however, increases the growth of nontransformed cells. Coordinate with tumor necrosis factor $\alpha$ induced mitogenesis of 3T3L 1 fibroblasts is the transcriptional induction of immediate early protooncogenes that are involved in the regulation of the cell cycle. Glucose transport increases as the result of translocation of Glut 1 to the cell surface, an apparent change in the glucose transporter intrinsic activity, and an increase in Glut $1 \mathrm{mRNA}$ due to an increase in its stability. Glut 4 is unaffected by tumor necrosis factor- $\alpha$ (206).

As a whole, these data indicate that mitogenesis, in general, is associated with an induction of Glut 1 expression, resulting in increased glucose transport.

\section{SUMMARY}

We have described the properties of glucose transporters expressed in several mammalian tissues and have summarized some of the adaptations that take place involving these molecules in various normal and abnormal states. With the exception of a few cell types, such as adipocytes and skeletal muscle, glucose transport is not a rate-limiting step in cellular glucose metabolism, and other substrates may be equally important for cellular metabolism. Nevertheless, an understanding of the mechanisms behind the regulation of glucose transport in individual tissues may facilitate an understanding of in vivo glucose utilization and clearance processes as they relate to normal and disease states. Although adult studies provide an impetus toward a mechanistic approach in preventing and treating various disease states involving derangements in glucose homeostasis, there remains a need for similar studies in the fetus and newborn. These developmental studies should help unravel the fetal/neonatal responses to normal and abnormal hormonal and substrate milieu.

\section{REFERENCES}

1. Wheeler TJ, Hinkle PC 1985 The glucose transporter of mammalian cells. Annu Rev Physiol 47:503-517

2. Lodish HF 1988 Anion-exchange and glucose transport proteins: structure, function, and distribution. Harvey Lect 82:19-46

3. Meddings JB, DeSouza D, Goel M, Thiesen S 1990 Glucose transport and microvillus membrane physical properties along the crypt-villus axis of the rabbit. J Clin Invest 85:1099-1107

4. Hediger MA, Coady MJ, Ikeda TS, Wright EM 1987 Expression, cloning and cDNA sequencing of the $\mathrm{Na}+$ /glucose cotransporter. Nature 330:379-381

5. Ikeda TS, Hwang E-S, Coady MJ, Hirayama BA, Hediger MA, Wright EM 1989 Characterization of a Nat/glucose cotransporter cloned from rabbit small intestine. J Membr Biol 110:87-95

6. Malo C, Berteloot A 1987 Proximo-distal gradient of Nat-dependent i)glucose transport activity in the brush border membrane vesicles from the human fetal small intestine. FEBS Lett 220:201-205

7. Turner RJ, Kempner ES 1982 Radiation inactivation studies of the renal brush-border membrane phlorizin-binding protein. J Biol Chem 257:10794-10797

8. Takahashi M, Malathi P, Prieser H, Jung CY 1985 Radiation inactivation studies on the rabbit kidney sodium-dependent glucose transporter. J Biol Chem 260:10551-10556

9. Aranson PS, Sacktor B 1975 The Na+ gradient-dependent transport of Dglucose in renal brush border membrane. J Biol Chem 250:6032-6039

10. Beck JC, Sacktor B 1975 Energetics of the Nat dependent transport of Dglucose in renal brush border membrane vesicles. J Biol Chem 250:86748680

11. Wright JK, Seckler R, Overath P 1986 Molecular aspects of sugar ion cotransport. Annu Rev Biochem 55:225-248

12. Hediger MA, Budard ML, Emanual BS, Mohandas TK, Wright EM 1989 Assignment of the human intestinal $\mathrm{Nat} /$ glucose gene (SGLT 1) to the q11.2 $\rightarrow$ qter region of chromosome 22 . Genomics 4:297-300

13. Bell GI, Kayano T, Buse JB, Burant CF, Takeda J, Lin D, Fukumoto H, Seino S 1990 Molecular biology of mammalian glucose transporters. Diabetes Care 13:198-208

14. Mueckler M 1990 Family of glucose-transporter genes: implications for glucose homeostasis and diabetes. Diabetes 39:6-11

15. Mueckler M, Caruso C, Baldwin SA, Panico M, Blench I, Morris HR, Allard WJ, Leinhard GE, Lodish HF 1985 Sequence and structure of a human glucose transporter. Science 229:941-945

16. Birnbaum M, Haspel HC, Rosen OM 1986 Cloning and characterization of a cDNA encoding the rat brain glucose-transporter protein. Proc Natl Acad Sci USA 83:5784-5788

17. Shows TB, Eddy RL, Byers MG, Fukushima Y, Dehaven CR, Murray JC, Bell GI 1987 Polymorphic human glucose transporter gene (GLUT) is on chromosome Ip31.3 - p35. Diabetes 36:546-549

18. Fukumoto $\mathrm{H}$, Seino S, Imura H, Seino Y, Eddy RL, Fukushima Y, Byers MG, Shows TB, Bell GI 1988 Identification of a human liver-type glucose transporter: cDNA sequence, expression and localization of the gene to chromosome 3. Proc Natl Acad Sci USA 85:5434-5438

19. Thorens B, Sarkar HK, Kaback HR, Lodish HF 1988 Cloning and functional expression in bacteria of a novel glucose transporter present in liver, intestine, kidney, and beta pancreatic islet cells. Cell 55:281-290

20. Permutt MA, Koranyi L, Keller K, Lacy PE, Scharp DW, Mueckler M 1989 Cloning and functional expression of a human pancreatic islet glucose transporter cDNA. Proc Natl Acad Sci USA 86:8688-8692

21. Kayano T, Fukumoto H, Eddy RL, Fan Y-S, Byers MG, Shows TB, Bell GI 1988 Evidence for a family of human glucose transporter-like proteins. J Biol Chem 263:15245-15248

22. James DE, Strube M, Mueckler M 1989 Molecular cloning and characterization of an insulin-regulatable glucose transporter. Nature 338:83-87 
23. Birnbaum MJ 1989 Identification of a novel gene encoding an insulinresponsive glucose transporter protein. Cell 57:305-315

24. Fukumoto H, Kayano T, Buse JB, Edwards Y, Pilch PF, Bell GI, Seino S 1989 Cloning and characterization of the major insulin-responsive glucose transporter expressed in human skeletal muscle and other insulin-responsive tissues. J Biol Chem 264:7776-7779

25. Bell GI, Murray JC, Nakamura Y, Kayano T, Eddy RL, Fan Y-S, Byers MG, Shows TB 1989 Polymorphic human insulin-responsive glucose transporter gene on chromosome 17p13. Diabetes 38:1072-1075

26. Kayano T, Burant CF, Fukumoto H, Gould GW, Fan Y-S, Eddy RL, Byers MG, Shows TB, Seino S, Bell GI 1990 Human facilitative glucose transporters. J Biol Chem 265:13276-13282

27. Zorzano A, Wilkinson W, Kotlial N, Thoidis G, Wadzinski BE, Ruoho AE Pilch PF 1989 Insulin-regulated glucose uptake in rat adipocytes is mediated by two transporter isoforms present in at least two vesicle populations. J Biol Chem 264:12358-12363

28. Holman GD, Kozka IJ, Clark AE, Flower CJ, Saltis J; Habberfield AD, Simpson IA, Cushman SW 1990 Cell surface labeling of glucose transporter isoform Glut 4 by bis-mannose photolabel. J Biol Chem 265:18172-18179

29. Koranyi L, James D, Mueckler M, Permutt MA 1990 Glucose transporte levels in spontaneously obese $(\mathrm{db} / \mathrm{db})$ insulin-resistant mice. $\mathrm{J}$ Clin Invest 85:962-967

30. Kern M, Wells JA, Stephens JM, Elton CW, Friedman JE, Tapscott EB, Pekala PH, Dohm GL 1990 Insulin responsiveness in skeletal muscle is determined by glucose transporter (Glut 4 ) protein level. Biochem J 170:397-400

31. Kahn BB, Rossetti L, Lodish HF, Charron MJ 1991 Decreased in vivo glucose uptake but normal expression of Glut 1 and Glut 4 in skeletal muscle of diabetic rats. J Clin Invest 87:2197-2206

32. Kahn BB, Cushman SW 1987 Mechanisms for markedly hyperresponsive insulin-stimulated glucose transport activity in adipose cells from insulintreated streptozotocin diabetic rats. J Biol Chem 262:5118-5124

33. Matthaei S, Garvey WT, Horuk R, Hueckstaedt TP, Olefsky JM 1987 Human adipocyte glucose transport system. J Clin Invest 79:703-709

34. Charron MJ, Kahn BB 1990 Divergent molecular mechanisms for insulinresistant transport in muscle and adipose cells in vivo. $J$ Biol Chem 265:7994-8000

35. Crofford OB, Renold AE 1965 Glucose uptake by incubated rat epididyma adipose tissue. Rate limiting steps and site of insulin action. J Biol Chem 240:3237-3244

36. Berger M, Hagg S, Ruderman NB 1975 Glucose metabolism in perfused skeletal muscle. Interaction of insulin and exercise on glucose uptake. Biochem J 146:231-238

37. Kuroda M, Honnor RC, Cushman SW, Londos C, Simpson IA 1987 Regulation of insulin-stimulated glucose transport in the isolated rat adipocyte. J Biol Chem 262:245-253

38. Suzuki K, Kono T 1980 Evidence that insulin causes translocation of glucose transport activity to the plasma membrane from an intracellular storage site. Proc Natl Acad Sci USA 77:2542-2545

39. Cushman SW, Wardzala LJ 1980 Potential mechanism of insulin action on glucose transport in the isolated rat adipose cell. J Biol Chem 255:47584762

40. Block J, Gibbs EM, Leinhard GE, Slot JW, Gueze HG 1988 Insulin-induced translocation of glucose transporters from post-Golgi compartments to the plasma membrane of 3T3L1 adipocytes. J Cell Biol 106:69-76

41. Slot JW, Gueze HJ, Gigengack S, Leinhard GE, James DE 1991 Immunolocalization of the insulin regulatable glucose transporter in brown adipose tissue of the rat. J Cell Biol 113:123-135

42. Calderhead DM, Kitagawa K, Tanner LI, Holman GD, Lienhard GE 1990 Insulin regulation of the two glucose transporters in 3T3L1 adipocytes. $\mathrm{J}$ Biol Chem 265:13801-13808

43. James DE, Lederman L, Pilch PF 1987 Purification of insulin-dependent exocytic vesicles containing the glucose transporter. J Biol Chem 262:11817-11824

44. Piper RC, Hess LJ, James DE 1991 Differential sorting of two glucose transporters expressed in insulin sensitive cells. Am J Physiol 260:C570C580

45. Slot JW, Moxley R, Gueze HJ, James DE 1990 No evidence for expression of the insulin-regulatable glucose transporter in endothelial cells. Nature 346:369-371

46. Kahn BB, Horton ES, Cushman W 1987 Mechanism for enhanced glucose transport response to insulin in adipose cells from chronically hyperinsulinemic rats. J Clin Invest 79:853-858

47. Kahn BB, Charron MJ, Lodish HF, Cushman SW, Flier JS 1988 Differentia regulation of two glucose transporters in adipose cells from diabetic and insulin-treated diabetic rats. J Clin Invest 84:404-4I 1

48. Bourey RE, Kornayi L, James DE, Mueckler M, Permutt MA 1990 Effects of altered glucose homeostasis on glucose transporter expression in skeletal muscle of the rat. J Clin Invest 86:542-547

49. Cusin I, Terrettaz J, Rohner-Jeanrenaud F, Zarjevski N, AssimacopoulosJeannet $F$, Jeanrenaud B 1990 Hyperinsulinemia increases the amount of GLUT 4 mRNA in white adipose tissue and decreases that of muscles: a clue for increased fat depot and insulin resistance. Endocrinology 127:32463248

50. Tordjman KM, Leingang KA, James DE, Mueckler MM 1989 Differentia regulation of two distinct glucose transporter species expressed in 3T3-L adipocytes: effect of chronic insulin and tolbutamide treatment. Proc Nat Acad Sci USA 86:7761-7765

51. Kozka IJ, Clark AE, Holman GD 1990 Chronic treatment with insulin selectively down-regulates cell-surface Glut 4 glucose transporters in 3T3L1 adipocytes. J Biol Chem 266:11726-11731

52. Tordjman KM, Leingang KA, Mueckler M 1990 Differential regulation of the Hep G2 and adipocyte/muscle glucose transporters in 3T3L1 adipocytes. Biochem J 271:201-207

53. Kovisto UM, Martinez-Valdez H, Bilan PJ, Burdett E, Ramlal T, Klip A 1991 Differential regulation of the Glut 1 and Glut 4 glucose transport systems by glucose and insulin in L6 muscle cells in culture. J Biol Chem $266: 2615-2621$

54. Maher F, Harrison LC 1990 Stabilization of glucose transporter mRNA by insulin/IGF-I and glucose deprivation. Biochem Biophys Res Commun 171:210-215

55. Cryer PE 1981 Glucose counterregulation in man. Diabetes 30:261-264

56. Santiago JV, Clarke WL, Shah SD, Cryer PE 1980 Epinephrine, norepinephrine, glucagon and growth hormone release in association with physiological decrements in the plasma glucose concentrations in normal and diabetic man. J Clin Endocrinol Metab 51:877-883

57. Joost HG, Weber TM, Cushman SW, Simpson IA 1987 Activity and phosphorylation state of glucose transporters in plasma membranes from insulin-, isoproterenol-, and phorbol ester-treated rat adipose cells. J Biol Chem 262:11261-11267

58. James DE, Hiken J, Lawrence Jr JC 1989 Isoproterenol stimulates phosphorylation of the insulin-regulatable glucose transporter in rat adipocytes. Proc Natl Acad Sci USA 86:8368-8372

59. Lawrence Jr J, Hiken JF, James DE 1990 Phosphorylation of the glucose transporters in rat adipocytes. J Biol Chem 265:2324-2332

60. Lawrence Jr JC, Hiken JF, James DE 1990 Stimulation of glucose transport and glucose transporter phosphorylation by okadaic acid in rat adipocytes. J Biol Chem 265:19768-19776

61. Kaestner KH, Flores-Riveros JR, McLenithan JC, Janicot M 1991 Transcriptional repression of the mouse insulin-responsive glucose transporter (Glut 4) gene by cAMP. J Biol Chem 88:1933-1937

62. Sato N, Irie M, Kajinuma H, Suzuki K 1990 Glucagon inhibits insulin activation of glucose transport in rat adipocytes mainly through a postbinding process. Endocrinology 127:1072-1077

63. Clancy BM, Czech MP 1990 Hexose transport stimulation and membrane redistribution of glucose transporter isoforms in response to cholera toxin, dibutyryl cyclic AMP, and insulin in 3T3-L1 adipocytes. J Biol Chem 265:12434-12443

64. Davidson MB 1987 Effect of growth hormone on carbohydrate and lipid metabolism. Endocr Rev 8:115-120

65. Rizza RA, Mandarino JL, Gerich JE 1982 Effects of growth hormone on insulin action in man. Mechanisms of insulin resistance, impaired suppression of glucose utilization. Diabetes 31:663-669

66. Ku-Tai P-K, Liano J-F, Chen EH, Dietz J, Schwartz J, Carter-Su C 1990 Differential regulation of two glucose transporters by chronic growth hormone treatment of cultured 3T3-F442A adipose cells. J Biol Chem $265: 21828-21834$

67. Carter-Su C, Okamoto K 1987 Effect of insulin and glucocorticoids on glucose transporters in rat adipocytes. Am J Physiol 252:E441-E453

68. Carter-Su C, Okamoto K 1985 Effect of glucocorticoids on hexose transport in rat adipocytes. J Biol Chem 260:1 1091-11098

69. Garvey WT, Hueckstaedt TP, Monzon R, Marshall S 1989 Dexamethasone regulates the glucose transport system in primary cultured adipocytes: different mechanisms of insulin resistance after acute and chronic exposure. Endocrinology 124:2063-2073

70. Sandler MP, Robinson RP, Rabin D, Lacy WW, Abumrad NN 1983 The effect of thyroid hormones on gluconeogenesis and forearm metabolism in man. J Clin Endocrinol Metab 56:479-485

71. Foss MC, Paccola GMCF, Saad MJA, Pimenta WP, Piccinato CE, Iaziqi $N$ 1990 Peripheral glucose metabolism in human hyperthyroidism. J Clin Endocrinol Metab 70:1167-1172

72. van Hardeveld C, Kassenaar AAH 1977 Influence of experimental hyperthyroidism on skeletal muscle metabolism in the rat. Acta Endocrinol (Copenh) $85: 71-83$

73. Randin J-P, Tappy L, Scazziga B, Jequier E, Felber J-P 1986 Insulin sensitivity and exogenous insulin clearance in Grave's disease. Diabetes 35:178-181

74. Brzezinska Z, Kaciuba-Uscilko H 1979 Low muscle and liver glycogen contents in dogs treated with thyroid hormones. Horm Metab Res 11:675678

75. Casla A, Rovira A, Wells JA, Dohm GL 1990 Increased glucose transporter (Glut 4) protein expression in hyperthyroidism. Biochem Biophys Res Commun 171:182-188

76. Horton ES 1986 Exercise and physical training: effects on insulin sensitivity and glucose metabolism. Diabetes Metab Rev 2:1-17

77. Berger M, Kemmer FW, Becker K, Herberg L, Schwenen R, Gjinavci A, Berchtold P 1979 Effect of physical training on glucose tolerance and on glucose metabolism of skeletal muscle in anesthetized normal rats. Diabetologia 16:179-184

78. James DE, Kraegen EW, Chisholm DJ 1984 The effect of exercise training on whole body insulin sensitivity and responsiveness. J Appl Physiol $56: 1217-1222$

79. James DE, Kraegen EW, Chisholm DJ 1984 The effect of exercise training 
on in vivo insulin action in individual tissues of the rat. J Clin Invest 76:657-666

80. Mondon CE, Dolkas CB, Reaven GM 1980 Site of enhanced insulin sensitivity in exercise-trained rats at rest. Am J Physiol 239:E169-E177

81. Ivy JL, Holloszy JO 1981 Persistent increase in glucose uptake by rat skeletal muscle following exercise. Am J Physiol 241:C200-C203

82. Wallberg-Henriksson H, Constable SH, Young DA, Holloszy JO 1988 Glucose transport into skeletal muscle: interaction between exercise and insulin. J Appl Physiol 65:909-913

83. Wallberg-Henriksson H, Holloszy JO 1984 Contractile activity increases glucose uptake by muscle in severely diabetic rats. J Appl Physiol 57:10451049

84. Wallberg-Henriksson H, Holloszy JO 1985 Activation of glucose transport in diabetic muscle: responses to contraction and insulin. Am J Physiol 249: $2233-\mathrm{C} 237$

85. Nesher R, Karl IE, Kipnis DM 1985 Dissociation of effects of insulin and contraction on glucose transport in rat epitrochlearis muscle. Am J Physiol 249:C226-C232

86. Douen AG, Ramlal T, Rastogi S, Bilan PJ, Cartee GD, Vranic M, Holloszy JO, Klip A 1990 Exercise induces recruitment of the "insulin-responsive glucose transporter." Evidence for distinct intracellular insulin- and exercise-recruitable transporter pools in skeletal muscle. J Biol Chem 265:13427-13430

87. Rodnick KJ, Holloszy JO, Mondon CE, James DE 1990 Effects of exercise training on insulin-regulatable glucose transporter protein levels in rat skeletal muscle. Diabetes 39:1425-1429

88. Fushiki T, Kano T, Inoue K, Sugimoto E 1991 Decrease in muscle glucose transporter number in chronic physical inactivity in rats. J Biol Chem 260:E403-E410

89. Karnieli E, Hissin PJ, Simpson IA, Salans LB, Cushman SW 1981 A possible mechanism of insulin resistance in the rat adipose cell in streptozotocininduced diabetes mellitus: depletion of intracellular glucose transport systems. J Clin Invest 68:811-814

90. Garvey WT, Huecksteadt TP, Birnbaum MJ 1989 Pretranslational suppression of an insulin-responsive glucose transporter in rats with diabetes mellitus. Science 245:60-63

91. Richardson JM, Balon TW, Treadway JL, Pessin JE 1991 Differential regulation of glucose transporter activity and expression in red and white skeletal muscle. J Biol Chem 266:12690-12694

92. Garvey GT, Huecksteadt TP, Matthaei S, Olefsky JM 1988 Role of glucose transporters in the cellular insulin resistance of type II non-insulin-dependent diabetes mellitus. J Clin Invest 81:1528-1536

93. Garvey WT, Maianu L, Hueckstaedt TP, Birnbaum MJ, Molina JM, Ciaraldi TP 1991 Pretranslational suppression of a glucose transporter protein causes insulin resistance in adipocytes from patients with non-insulin-dependent diabetes mellitus and obesity. J Clin Invest 87:1072-1081

94. Baron AD, Laakso M, Brechtel G, Edelman SV 1991 Reduced capacity and affinity of skeletal muscle for insulin-mediated glucose uptake in noninsulin-dependent diabetic subjects. J Clin Invest 87:1186-1194

95. Pederson O, Bak JF, Anderson PH, Lund S, Moller DE, Flier JS, Kahn BB 1990 Evidence against altered expression of Glut 1 or Glut 4 in skeletal muscle of patients with obesity or NIDDM. Diabetes 39:865-870

96. Dohm GL, Elton CW, Friedman JE, Pilch PF, Pories WJ, Atkinson Jr SM, Caro JF 1991 Decreased expression of glucose transporter in muscle from insulin-resistant patients. Am J Physiol 260:E459-E463

97. Kahn BB, Shulman GI, DeFronzo RA, Cushman SW, Rossetti L 1991 Normalization of blood glucose in diabetic rats with phlorizin treatmen reverses insulin-resistant glucose transport in adipose cells without restoring glucose transporter gene expression. J Clin Invest 87:561-570

98. Simonson DE, Ferrannini E, Stefano B, Smith D, Barrett E, Carlson R, DeFronzo RA 1984 Mechanisms of improvement in glucose metabolism after chronic glyburide therapy. Diabetes 33:838-845

99. Grodsky GM, Epstein GM, Franska R, Karam JH 1977 Pancreatic action of the sulphonylureas. Fed Proc 36:2714-2719

100. Yalow RS, Black H, Villazon M, Berson SA 1960 Comparison of plasma insulin levels following administration of tolbutamide and glucose. Diabetes 9:356-362

101. Feldman J, Lebovitz H 1969 An insulin-dependent effect of chronic tolbutamide administration on the skeletal muscle carbohydrate transport system. Diabetes 18:84-95

102. Lebovitz HE, Feinglos MN, Bucholtz HK, Lebovitz FL 1977 Potentiation of insulin action: a probable mechanism for the anti-diabetic action of sulphonylurea drugs. J Clin Endocrinol Metab 45:601-604

103. Jacobs DB, Jung CY 1985 Sulfonylurea potentiates insulin-induced recruitment of glucose transport carrier in rat adipocytes. J Biol Chem 260:25932596

104. Wang PH, Moller D, Flier JS, Nayak RC, Smith RJ 1989 Coordinate regulation of glucose transporter function, number, and gene expression by insulin and sulfonylureas in L6 rat skeletal muscle cells. J Clin Invest 84:62-67

105. Meyerovitch J, Rothenberg P, Schechter Y, Bonner-Weir S, Kahn CR 1991 Vanadate normalizes hyperglycemia in two mouse models of non-insulin dependent diabetes mellitus. J Clin Invest 87:1286-1294

106. Strout HV, Vicario PP, Biswas C, Saperstein R, Brady EJ, Pilch PF, Berger J 1990 Vanadate treatment of streptozotocin diabetic rats restores expression of the insulin-responsive glucose transporter in skeletal muscle. Endocrinology 126:2728-2732
107. Sinha MK, Taylor LG, Pories WJ, Flickinger EG, Meelheim D, Atkinson S, Sehgal NS, Caro JF 1987 Long-term effect of insulin on glucose treatment and insulin binding in cultured adipocytes from normal and obese humans with or without non-insulin dependent diabetes. J Clin Invest 80:10731081

108. Kahn BB, Cushman SW 1985 Subcellular translocation of glucose transporters: role in insulin action and its perturbation in altered metabolic states. Diabetes Metab Rev 1:203-227

109. Le Marchand-Brustel Y, Olichon-Berther C, Bremeaux T, Tanti J-F, Rochet N, Van Obberghen E 1990 Glucose transporter in insulin sensitive tissues of lean and obese mice: effect of the thermogenic agent BRL 26830A. Endocrinology 127:2687-2695

110. Kahn BB, Simpson IA, Cushman SW 1988 Divergent mechanisms for the insulin resistant and hyperresponsive glucose transport in adipose cells from fasted and refed rats. J Clin Invest 82:691-699

111. Berger J, Biswas C, Vicario PP, Strout HV, Saperstein R, Pilch PF 1989 Decreased expression of the insulin-responsive glucose transporter in diabetes and fasting. Nature 340:70-72

112. Sivitz WI, deSautel SL, Kayano T, Bell GI, Pessin JE 1989 Regulation of glucose transporter messenger RNA in insulin deficient states. Nature 340:72-74

113. Penicaud L, Kinde J, LeMagnen J, Girard JR 1985 Insulin action during fasting and refeeding in rat determined by euglycemic clamp. Am J Physiol 249:E514-E518

114. Neuman WP, Bradows RG 1983 Insulin action during acute starvation: evidence for selective insulin resistance in normal man. Metabolism 32:590-596

115. Hissin PJ, Karnieli E, Simpson IA, Salans LB, Cushman SW 1982 A possible mechanism of insulin resistance on the rat adipose cell with high fat/low carbohydrate feeding: depletion of intracellular glucose transport systems. Diabetes 31:589-592

116. Hissin PJ, Foley JF, Wardzala LJ, Karnieli E, Simpson IA, Salans LB, Cushman SW 1982 Mechanism of insulin-resistant glucose transport activity in the enlarged adipose cell of the aged, obese rat: relative depletion of intracellular glucose transport systems. J Clin Invest 70:780-790

117. Ezaki O, Fukuda N, Itakura H 1990 Role of two types of glucose transporters in enlarged adipocytes from aged obese rats. Diabetes 39:1543-1549

118. Jacobs DB, Hayes GR, Truglia JA, Lockwood DH 1989 Alterations of glucose transporter systems in insulin-resistant uremic rats. Am J Physiol 257:E193-E197

119. Hiraki Y, Rosen OM, Birnbaum MJ 1988 Growth factors rapidly induce expression of the glucose transporter gene. J Biol Chem 263:13655-13662

120. Wang C, Brennan Jr WA 1988 Rat skeletal muscle, liver and brain have different fetal and adult forms of the glucose transporter. Biochim Biophys Acta 946:11-18

121. Werner H, Adamo M, Lowe Jr WL, Roberts Jr CT, LeRoith D 1989 Developmental regulation of the rat brain/Hep G2 glucose transporter gene expression. Mol Endocrinol 3:273-279

122. Bloch CA, Banach W, Landt K, Devaskar S, Sperling MA 1986 Effects of fetal insulin infusion on glucose kinetics in pregnant sheep: a compartmental analysis. Am J Physiol 251:E448-E456

123. Mantych G, Devaskar U, deMello D, Devaskar S 1991 Glut 1 glucose transporter protein in adult and fetal mouse lung. Biochem Biophys Res Commun 180:367-373

124. Leturque A, Postic C, Ferre P, Girard J 1991 Nutritional regulation of glucose transporter in muscle and adipose tissue of weaned rats. Am J Physiol 260:E588-E593

125. Kaestner KH, Christy RJ, Lane MD 1990 Mouse insulin-responsive glucose transporter gene: characterization of the gene and transactivation by the CAAT/enhancer binding protein. Proc Natl Acad Sci USA 87:251-255

126. Li SR, Baroni MG, Oelbaum RS, Stock J, Galton DJ 1988 Association of genetic variant of the glucose transporter with non-insulin-dependent diabetes mellitus. Lancet 2:368-370

127. Cox NJ, Xiang K-S, Bell GI, Karam JH 1988 Glucose transporter gene and non-insulin-dependent diabetes. Lancet 2:793-794

128. Kaku K, Matsutani A, Mueckler M, Permutt MA 1990 Polymorphisms of Hep G2/erythrocyte glucose transporter gene: linkage relationships and implications for genetic analysis of NIDDM. Diabetes 39:49-56

129. Xiang K-S, Cox NJ, Sanz N, Huang P, Karam JH, Bell GI 1989 Insulinreceptor and apolipoprotein genes contribute to development of NIDDM in Chinese Americans. Diabetes 37:17-23

130. Matsutani A, Koranyi L, Cox N, Permutt MA 1990 Polymorphisms of Glut 2 and Glut 4 genes. Diabetes 39:1534-1542

131. Tal M, Schneider DL, Thorens B, Lodish HF 1990 Restricted expression of the erythroid/brain glucose transporter isoform to perivenous hepatocytes in rats. J Clin Invest 86:986-992

132. Gould GW, Thomas HM, Jess TJ, Bell GI 1991 Expression of human glucose transporters in xenopus oocytes: kinetic characterization and substrate specificities of the erythrocyte, liver and brain isoforms. Biochemistry 30:5139-5145

133. Meglasson MD, Matchinsky FM 1986 Pancreatic islet glucose metabolism and regulation of insulin secretion. Diabetes Metab Rev 2:163-214

134. Orci L, Thorens B, Ravazzola M, Lodish HF 1989 Localization of the pancreatic B-cell glucose transporter to specific plasma membrane domains. Science 21:295-297

135. Oka Y, Asano T, Shibasaki Y, Lin J-L, Tsukuda K, Akanuma Y, Takaku F 
1990 Increased liver glucose transporter protein and mRNA in streptozotocin-induced diabetic rats. Diabetes 39:441 -446

136. Thorens B, Flier JS, Lodish HF, Kahn BB 1990 Differential regulation of two glucose transporters in rat liver by fasting and refeeding and by diabetes and insulin treatment. Diabetes 39:712-719

137. Johnson JH, Ogawa A, Chen L, Orci L, Newgard CB, Alam T, Unger RH 1990 Underexpression of beta cell high $\mathrm{Km}$ glucose transporters in noninsulin-dependent diabetes. Science 250:546-548

138. Orci L Unger RH, Ravazzola M Ogawa A, Komiya I, Baetens D, Lodish HF, Thorens B 1990 Reduced beta cell glucose transporter in new onset diabetic BB rats. J Clin Invest 86:1615-1622

139. Chen L, Alam T, Johnson JH, Hughes S, Newgard CB, Unger RH 1990 Regulation of beta-cell glucose transporter gene expression. Proc Natl Acad Sci USA 87:4088-4092

140. Johnson JH, Crider BP, McCorkle K, Alford M, Unger RH 1990 Inhibition of glucose transport into rat islet cells by immunoglobulins from patients with new-onset insulin-dependent diabetes mellitus. N Engl J Med 322:653659

141. Chundu K, Devaskar S 1988 The ontogeny of the rabbit hepatic glucose transporter. Biochem Biophys Res Commun 155:173-180

142. Axelrod JD, Pilch PF 1983 Unique cytochalasin B binding characteristics of the hepatic glucose carrier. Biochemistry 22:2222-2227

143. Girard JR, Cuendet GS, Marliss EB, Kervran A, Rieutort M, Asan R 1973 Fuels, hormones and liver metabolism in term and during the early postnatal period in rat. $\mathrm{J}$ Clin Invest $52: 3190-3200$

144. Girard J, Guillet I, Marty J, Marliss EB 1975 Plasma amino acid levels and development of hepatic gluconeogenesis in the newborn rat. Am J Physiol 229:E466-E473

145. Cahill GF 1970 Starvation in man. N Engl J Med 282:668-675

146. Thorens B, Lodish HF, Brown D, 1990 Differential localization of two glucose transporter isoforms in rat kidney. Am J Physiol 259:C286-C294

147. Thorens B, Cheng ZQ, Brown D, and Lodish HF 1990 Liver glucose transporter: a basolateral protein in hepatocytes and intestine and kidney cells. Am J Physiol 259:C279-C285

148. Haspel HC, Mynarcik DC, Ortiz PA, Honkanen RA, Rosenfeld MG 1991 Glucose deprivation induces the selective accumulation of hexose transporter protein GLUT-1 in the plasma membrane of normal rat kidney cells. Mol Endocrinol 5:61-72

149. Fujii Y, Kaizuka M, Hashida F, Maruo J, Sato E, Yasuda H, Kurokawa T, Ishibashi $\mathrm{S} 199 \mathrm{I}$ Insulin regulates $\mathrm{Na}+$ /glucose cotransporter activity in rat small intestine. Biochim Biophys Acta 1063:90-94

150. Beck JC, Lipkowitz MS, Abramson RG 1988 Characterization of the fetal glucose transporter in rabbit kidney. J Clin Invest 82:379-387

151. Turk E, Zabel B, Mundlos S, Dyer J, Wright EM 1991 Glucose-galactose malabsorption caused by a defect in the sodium-glucose cotransporter. Nature 350:354-356

152. Scheinberg P 1965 Observations on cerebral carbohydrate metabolism in man. Ann Intern Med 62:367-371

153. Bagley PR, Tucker SP, Nolan C, Lindsay JG, Davies A, Baldwin SA, Cremer JE, Cunningham VJ 1989 Anatomical mapping of glucose transporter protein and pyruvate dehydrogenase in rat brain: an immunogold study. Brain Res 499:214-224

154. Kasanicki MA, Jessen KR, Baldwin SA, Boyle JM, Davies A, Gardiner RM 1989 Immunocytochemical localization of the glucose-transport protein in mammalian brain capillaries. Histochem J 21:47-51

155. Kalaria RN, Gravina SA, Schmidley JW, Perry G, Harik SI 1988 The glucose transporter of the human brain and blood-brain barrier. Ann Neurol 24:757-764

156. Gerhart DZ, LeVasseur RJ, Broderius MA, Drewes LR 1989 Glucose transporter localization in brain using light and electron immunocytochemistry. J Neurosci Res 22:464-472

157. Farrel CL, Partridge WM 1991 Blood-brain barrier glucose transporter is asymmetrically distributed on brain capillary endothelial lumenal and alblumenal membranes: an electron microscopic immunogold study. Proc Natl Acad Sci USA 88:5779-5783

158. Pardridge WM, Boado RJ, Farrel CR 1990 Brain-type glucose transporter (GLUT 1) is selectively localized to the blood-brain barrier. J Biol Chem 265:18035-18040

159. Sadiq F, Holtzclaw L, Chundu K, Muzzafar A, Devaskar S 1990 The ontogeny of the rabbit brain glucose transporter. Endocrinology 126:2417-2424

160. Devaskar S 1991 The mammalian brain glucose transport system. In: LeRoith D, Raizada MK (eds) Molecular Biology and Physiology of Insulin and Insulin-Like Growth Factors, Vol 293. Plenum Press, New York, pp 405417

161. Clarke DW, Boyd Jr FT, Kappy MS, Raizada MK 1984 Insulin binds to specific receptors and stimulates 2-deoxy-D-glucose uptake in cultured glial cells from rat brain. J Biol Chem 259:11672-11675

162. Boyd Jr FT, Clarke DW, Muther TF, Raizada MK 1985 Insulin receptors and insulin modulation of norepinephrine uptake in neuronal cultures from rat brain. J Biol Chem 260:15880-15885

163. McCall AL, Fixman LB, Fleming N, Tornheim K, Chick W, Ruderman NB 1986 Chronic hypoglycemia increases brain glucose transport. Am J Physiol 251:E442-E447

164. Garris DR, Michel ME 1988 Regional brain glucose uptake in genetically diabetic C57BL/KsJ mice: modulation by the opiate antagonist, Nalmefene. Brain Res 445:262-267

165. Choi TB, Boado RJ, Pardridge WM 1989 Blood-brain barrier glucose trans- porter mRNA is increased in experimental diabetes mellitus. Biochem Biophys Res Commun 164: 375-380

166. Pardridge WM, Triguero D, Farrell CR 1990 Downregulation of blood-brain barrier glucose transporter in experimental diabetes. Diabetes 39:10401044

167. Koranyi L, Bourey RE, James DE, Mueckler M, Fiedorek FT, Permutt MA 1991 Glucose transporter gene expression in rat brain: pretranslational changes associated with chronic insulin induced hypoglycemia, fasting and diabetes. Mole Cell Neurosci 2:244-252

168. Walker PS, Donovan JA, Van Ness BG, Fellows RE, Pessin JE 1988 Glucosedependent regulation of glucose transport activity, protein, mRNA in primary cultures of rat brain glial cells. J Biol Chem 263:15594-15601

169. Werner H, Raizada MK, Mudd LM, Foyt HL, Simpson IA, Roberts Jr CT, LeRoith D 1989 Regulation of rat brain/Hep G2 glucose transporter gene expression by insulin and insulin-like growth factor-I in primary cultures of neuronal and glial cells. Endocrinology 125:314-320

170. Masters BA, Werner H, Roberts Jr CT, LeRoith C, Raizada MK 1991 Developmental regulation of insulin-like growth factor I-stimulated glucose transporter in rat brain astrocytes. Endocrinology 128:2548-2557

171. Sivitz W, DeSautel S, Walker PS, Pessin JE 1989 Regulation of the glucose transporter in developing rat brain. Endocrinology 124:1875-1880

172. Fuglsang A, Lomholt M, Gjedde A 1986 Blood-brain transfer of glucose and glucose analogs in newborn rats. J Neurochem 46:1417-1428

173. Spatz M, Micic D, Mrulja BB, Swink M, Micic J 1978 Changes in the capillary lactate and 2-deoxy-D-glucose uptake in developing brain. Brain Res 151:619-622

174. Devaskar S, Zahm DS, Holtzclaw L, Chundu K, Wadzinski BE 1991 Developmental regulation of the distribution of rat brain insulin-insensitive (Glut 1) glucose transporter. Endocrinology 129:1530-1540

175. Bassett DJP, Bowen-Kelly E, Reichenbausch SS 1989 Rat lung glucose metabolism after 24 hour exposure to 100\% oxygen. J Appl Physiol 66:989996

176. Maniscalo WM, Wilson CM, Gross I, Gobram L, Rooney SA, Warshaw JB 1978 Development of glycogen and phospholipid metabolism in fetal and newborn rat lung. Biochim Biophys Acta 530:333-346

177. Van Golde LMG 1976 Metabolism of phospholipids in the lung. Am Rev Respir Dis 114:977-1000

178. Bourbon JR, Rieutort M, Engle MJ, Farrell PM 1982 Utilization of glycogen for phospholipid synthesis in fetal rat lung. Biochim Biophys Acta 712:382389

179. Bourbon J, Jost A 1982 Control of glycogen metabolism in the developing fetal lung. Pediatr Res 16:50-56

180. Gewolb IH, Barrett C, Wilson CM, Warshaw JB 1982 Delay in pulmonary glycogen degradation in fetuses of streptozotocin diabetic rats. Pediatr Res 16:869-873

181. Tsai MY, Josephson MW, Howe JD 1983 Delayed pulmonary phosphatidyl glycerol synthesis and reversal by premature dexamethasone in fetal rats of streptozotocin diabetic mothers. Exp Lung Res 4:315-323

182. Warburton D 1983 Chronic hyperglycemia inhibits surface active material flux in tracheal fluid of fetal lamb. J Clin Invest 71:550-555

183. Robert MF, Neff R, Hubbell J, Tawusch HW, Avery ME 1976 Association between maternal diabetes and respiratory distress syndrome in the newborn. N Engl J Med 294:357-360

184. Bassett G, Crone C, Saumon G 1987 Fluid absorption by rat lung in situ: pathways for sodium entry in the luminal membrane of alveolar epithelium. J Physiol (Lond) 384:325-345

185. Barker PM, Boyd CAR, Ramsden CA, Strang LB, Walters DV 1989 Pulmonary glucose transport in the fetal sheep. J Physiol (Lond) 409:15-28

186. Bassett G, Saumon G, Aouchonnet F, Crone C 1988 Apical sodium-sugar transport in pulmonary epithelium in situ. Biochim Biophys Acta 942:1118

187. Strang LB 1989 Solute and water transport across the pulmonary epithelium: a new chapter in lung physiology inaugurated by Alfred Jost. Biol Neonate 55:355-365

188. Clerci C, Soler P, Saumon G 1991 Sodium-dependent phosphate and alanine transports but sodium-independent hexose transport in type III alveola epithelial cells in primary culture. Biochim Biophys Acta 1063:27-35

189. Bissonette JM, Black JA, Wickham WK, Acott KM 1981 Glucose uptake into plasma membrane vesicles from the maternal surface of human placenta. J Membr Biol 58:75-80

190. Wheeler CPD, Yudilevich DL 1989 Effect of insulin, prostaglandin E1 and uptake inhibitors on glucose transport in the perfused guinea-pig placenta. J Dev Physiol 11:159-169

191. Simmons MA, Battaglia FC, Meschia G 1979 Placental transfer of glucose. J Dev Physiol 1:227-242

192. Takata K, Kasahara T, Kasahara M, Ezaki O, Hirano H 1990 Erythrocyte/ Hep G2-type glucose transporter is concentrated in cells of blood-tissue barriers. Biochem Biophys Res Commun 173:67-73

193. Thomas CR, Eriksson GL, Eriksson UJ 1990 Effects of maternal diabetes on placental transfer of glucose in rats. Diabetes 39:276-282

194. Abramovich A, Sporn J, Prager R, Shaltiel A, Laron Z, Liban E 1978 Glycogen metabolism in the placenta of streptozotocin diabetic rats. Horm Metab Res 195-199

195. Barash V, Gutman A, Shafir E 1983 Mechanism of placental glycogen deposition in diabetes in the rat. Diabetologia 24:63-68

196. Jansson T, Persson E 1990 Placental transfer of glucose and amino acids in 
intrauterine growth retardation: studies with substrate analogs in the awake guinea pig. Pediatr Res 28:203-208

197. Lueder FL, Ogata ES 1990 Uterine artery ligation in the maternal rat alters fetal tissue glucose utilization. Pediatr Res 28:464-468

198. Lueder FL, Buroker CA, Gounis AS, Ogata ES 1990 Differential effects of acute and chronic maternal hypoglycemia upon fetal rat tissue glucose utilization. Clin Res 38:(3)A(abstr 838A)

199. Yamamoto $T$, Seino $Y$, Fukumoto $H$, Koh $G$, Yano $H$, Inagaki $N$, Yamada Y, Inoue K, Manabe T, Imura H 1990 Over-expression of facilitative glucose transporter genes in human cancer. Biochem Biophys Res Commun $170: 223-230$

200. Su T-S, Tsai T-F, Chi C-W, Han S-H, Chou C-K 1990 Elevation of facilitated glucose-transporter messenger RNA in human hepatocellular carcinoma. Hepatology 11:118-122

201. Yamada Y, Seino Y, Takeda J, Fukumoto H, Yano H, Inagaki N, Fukuda $Y$, Seino $S$, Imura $H 1990$ Increase in liver glucose transporter mRNA levels during rat liver regeneration. Biochem Biophys Res Commun 168:1274-1279

202. Flier JS, Mueckler MM, Usher P, Lodish HF 1987 Elevated levels of glucose transporter and transporter messenger RNA are induced by ras and src oncogenes. Science 235:1492-1495

203. White MK, Weber MJ 1990 The src oncogene can regulate a human glucose transporter expressed in chicken embryo fibroblasts. Mol Cell Biol 10:13011306

204. Mudd LM, Werner H, Shen-Orr Z, Roberts Jr CT, LeRoith D, Haspel HC, Raizada MK 1990 Regulation of rat brain/Hep G2 glucose transporter gene expression by phorbol esters in primary cultures of neuronal and astrocytic glial cells. Endocrinology 126:545-549

205. Witters LA, Vater CA, Lienhard GE 1985 Phosphorylation of the glucose transporter in vitro and in vivo by protein kinase C. Nature 315:777-778

206. Cornelius P, Marlowe M, Lee MD, Pekala PH 1990 The growth factor-like effects of tumor necrosis factor-alpha. J Biol Chem 265:20506-20516

\section{Announcement \\ THE ASSOCIATION OF MEDICAL SCHOOL PEDIATRIC DEPARTMENT CHAIRMEN, INC. proudly announces the Pediatric Scientist Development Program 1991 Fellows}

Elizabeth F. Bernstein, M.D.

Gary S. Gottesman, M.D.

Melissa J. Gregory, M.D.

David B. Haslam, M.D.

Yuk M. Law, M.D.

Timothy W. Ryschon, M.D.
Frank A. Oski, M.D. Johns Hopkins University

Harvey R. Colten, M.D. Washington University

Robert P. Kelch, M.D. University of Michigan

Robert G. Peterson, M.D. University of Ottawa

Joseph B. Warshaw, M.D. Yale University

Michael A. Simmons, M.D. University of Utah

We gratefully acknowledge the support and sponsorship of

National Institute of Child Health and Human Development

The March of Dimes Birth Defects Foundation

The Cystic Fibrosis Foundation

The St. Jude Children's Research Hospital

The William T. Grant Foundation

The American Academy of Pediatrics

The Johnson \& Johnson Institute for Pediatric Service 